\title{
Role of the Centrosomal MARK4 Protein in Gliomagenesis
}

\author{
Ivana Magnani, Chiara Novielli and Lidia Larizza \\ Università degli Studi di Milano \\ Italy
}

\section{Introduction}

Human gliomas are the most frequent tumours of the central nervous system (Kleihues \& Cavenee, 2000). They are of neuroectodermal origin and present as different histological types and malignancy grades (Louis et al., 2007).

According to the WHO (world health organization) system, astrocytoma, oligodendroglioma and mixed oligoastrocytoma are classified as differentiated gliomas, while anaplastic glioma and glioblastoma show increasing grades of malignancy (Box 1).

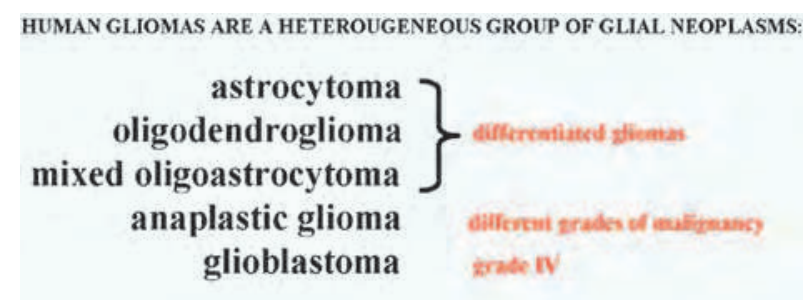

Box 1.

Gliomas are composed of different cell types displaying, even within low-grade tumours, a wide spectrum of heterogeneity regarding morphology, genotype, invasive potentiality, and treatment sensitivity (Noble \& Dietrich, 2004). The development and progression of glioma malignancies is driven by accumulation of genomic alterations, including both mutations and chromosomal instability (CIN).

\section{Chromosomal instability (CIN) in glioma}

CIN refers to the rate of lost or gained chromosomes and/or structural chromosome anomalies and ploidy changes during cell divisions (Geigl et al., 2008; Lengauer et al., 1998). Structural chromosome anomalies (translocations, deletions, insertions, inversion and additions) may be balanced or unbalanced and involve one or more chromosomes (Bayani et al., 2007). Chromosomal instability in glioma is mainly characterized by aneuploidy (Bigner et al., 1988; Hecht et al., 1995; Jenkins et al., 1989; Lindstrom et al., 1991; Magnani et al., 1994; Park et al., 1995; Thiel et al., 1992) affecting in particular glioblastoma, the most 
malignant glioma. Gliomas frequently display near-diploid $(2 \mathrm{n}+/-)$ and/or near-tritetraploid $(3 n+/-) /(4 n+/-)$ karyotypes, implicating aberrant mitotic divisions, in addition to chromosomal rearrangements. Highly polyploid subpopulations and the presence of apoptotic nuclei are also reported (Figures 1a-d).

a

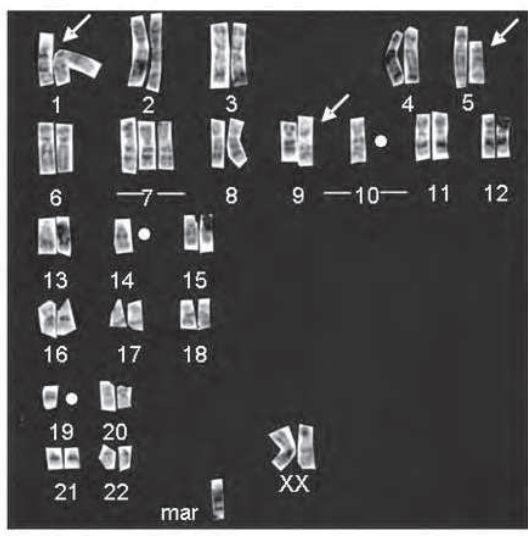

c

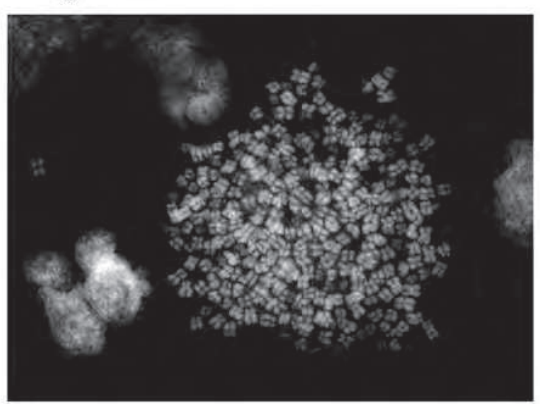

b

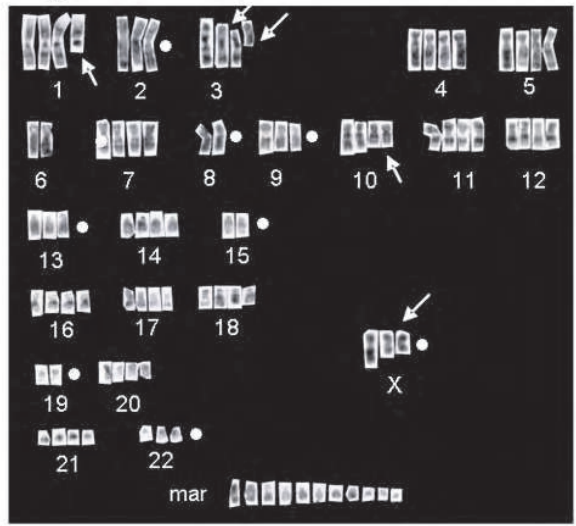

d

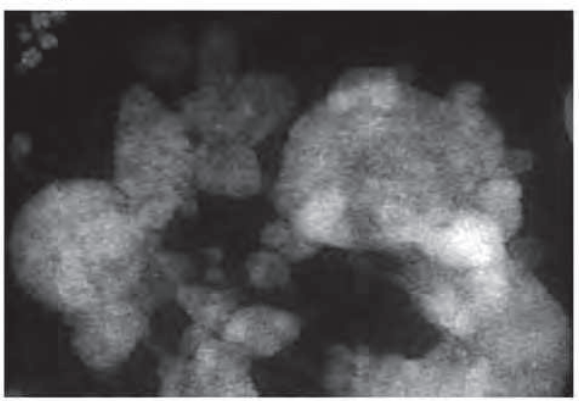

Fig. 1. (a) The G-banded, near diploid karyotype of MI-4 GBM (glioblastoma multiforme) cell line (Magnani et al., 1994), showing trisomy of chromosome 7, monosomy of chromosome 10 and a complex rearrangement involving chromosomes 1, 9 and 19. (b) The G-banded, near tetraploid karyotype of MI-4 cell line, displaying several chromosome losses and structural rearrangements including marker chromosomes. (c) Representative polyploid metaphase from MI-60 GBM cell line, characterized by a high frequency of hyperdiploid cells. (d) Apoptotic and large nuclei of MI-60 cell line.

Low-grade astrocytomas and oligodendrogliomas (WHO grades I-II) show a number of chromosome aberrations quite low. When present, they involve the gain of chromosome 7 , the loss of chromosomes 10, 22 and one sex chromosome (see Figures 1a, b), while structural changes affect in particular $1 p$ (Figure 2a) and 9p (Figure 2b) chromosome arms.

These chromosome abnormalities are qualitatively similar to those found in anaplastic astrocytoma (WHO grade III) and glioblastoma (WHO grade IV), but their frequency is 
increased in the latter and multiple chromosomal rearrangements are also present. The finding of common abnormalities associated to both low- and high-grade glioma has suggested a progressive chromosomal evolution during tumour growth (Bigner et al., 1988; Jenkins et al., 1989; Magnani et al., 1994; Thiel et al., 1992) even though it has been demonstrated that a subset of glioblastomas arises clonally de novo, further emphasizing the genetic heterogeneity of glioma (Kleihues \& Ohgaki, 2000; von Deimling et al., 1993). Given that numerical CIN features many cancer cells, it has been hypothesized that it may have a primary role in tumorigenesis (Duesberg et al., 2006; Weaver et al., 2007). Recently it has been shown that the main pathway to aneuploidy in cancer cells is triggered by extra centrosomes that, increasing improper merotelic attachments of kinetochores to spindle microtubules, cause chromosome mis-segregation (Meraldi et al., 2002) (Figure 3) (see Box 3 for centrosomes and Box 4 for mitotic spindle).
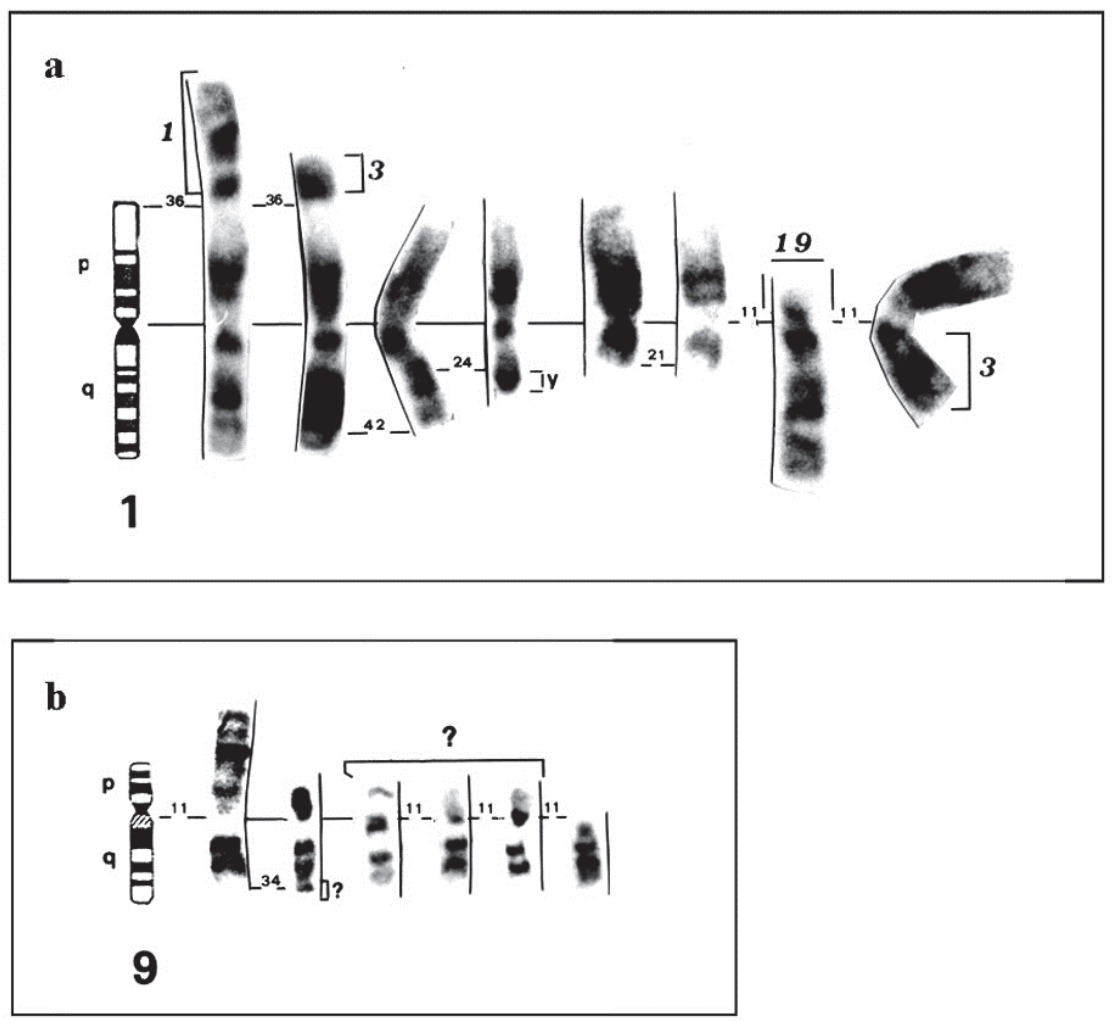

Fig. 2. (a) Chromosome 1 rearrangements of both $\mathrm{p}$ and $\mathrm{q}$ arms observed in different glioma cell lines by G-banding. (b) Rearrangements of chromosome 9p, sharing the loss of p21 band, observed in different glioblastoma cell lines by G-banding.

At early mitosis, the merotelic orientation escapes the spindle mitotic checkpoint thus representing the major mechanism of chromosome mis-segregation in non-cancer cells. Usually these errors are corrected before cells enter anaphase, to preserve genome stability (Cimini et al., 2004). 


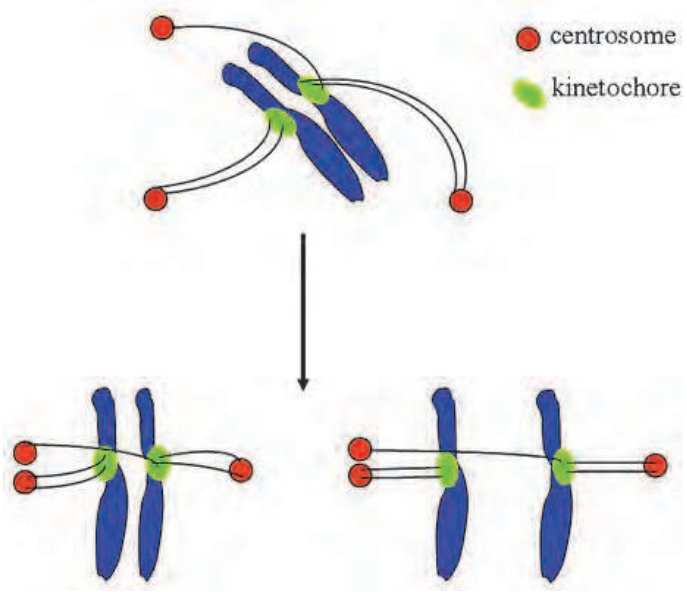

Fig. 3. Proposed events of lagging chromosomes in cancer cells with extra centrosomes through merotelic kinetochore orientation. (top) In the presence of extra centrosomes (three instead of two, as example), merotelic kinetochore orientation may occur: one kinetochore is bound by spindle microtubules from two centrosomes (right) instead of just one (left). (bottom) As cells move to mitosis and cluster extra centrosomes in a bipolar spindle, many attachment errors persist into anaphase, leading to lagging chromosomes.

\section{Tetraploidy, centrosome amplification and spontaneous chromosomal instability in glioma}

A relationship between extra centrosomes and the formation of multipolar spindles in cancer cells has been proposed by different authors (Basto et al., 2008; Cimini et al., 2004; Saunders, 2005; Sluder \& Nordberg, 2004). Multipolarity in cancer cells is considered an essential transient stage prior to clustering extra centrosomes in a bipolar fashion (Brinkley, 2001). Multiple centrosomes have been detected in many types of cancer cells including glioma (Figure 4) and strongly linked to aneuploidy in a variety of studies (D'Assoro et al., 2002; Ganem et al., 2009; Ghadimi et al., 2000; Katsetos et al., 2006; Lingle et al., 2002; Magnani et al., 2009; Pihan et al., 1998).

A positive linear correlation between the percentage of cells with supernumerary centrosomes and the extent of aneuploidy within a panel of glioblastoma cell lines is shown in Figure 5.

In tumour development, aneuploidy is frequently preceded by tetraploidy, often with prolonged tetraploid precancerous status, a feature that makes it of central importance to cancer research (Margolis et al., 2003). It has been proposed that failure of cytokinesis is a key step in the formation of tetraploid karyotypes and in tumour initiation (Fujiwara et al., 2005). A tetraploid cell inherits twice the normal complement of centrosomes, a condition assessed to generate chromosomes mis-segregation in subsequent cell divisions (Ganem et al., 2007). However, tetraploid cells are observed in some normal tissues including liver and heart, indicating that cytokinesis is physiologically regulated. The possible fate of a tetraploid progeny is shown in Figure 6. 

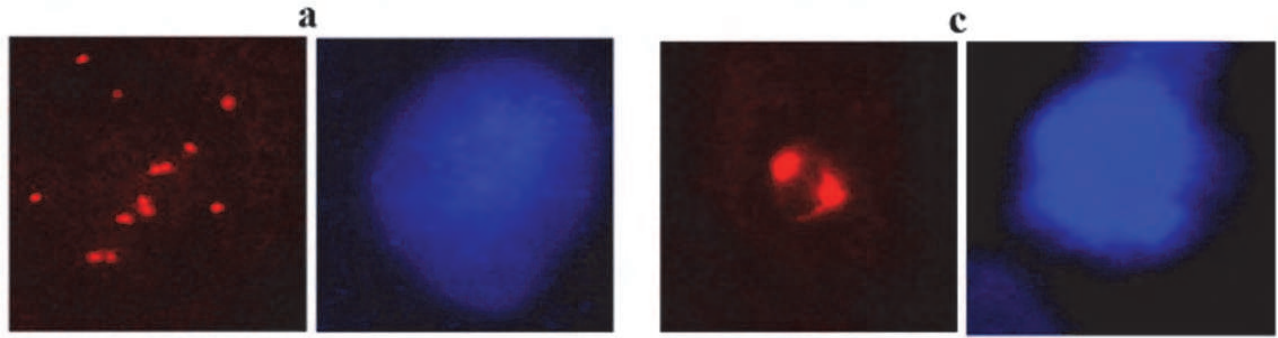

d

\section{b}
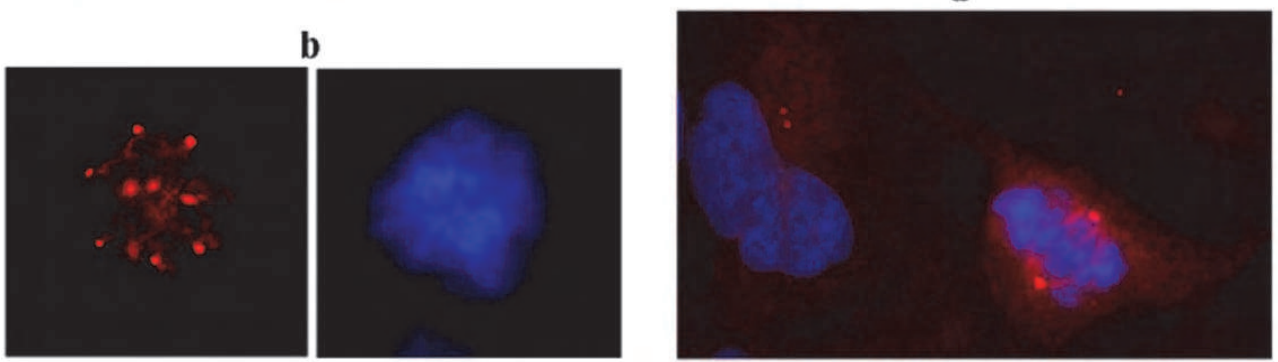

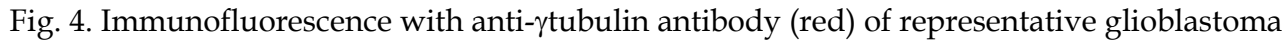
cell lines, showing (a) multiple centrosomes; (b) multipolar spindles; (c) a mitotic bipolar spindle in which centrosomes are larger than the normal one (likely extra centrosomes clustered into two spindle poles), a condition that favours mitotic stability and neoplastic growth; (d) normal centrosomes and a mitotic bipolar spindle configuration. The nuclei are counterstained with DAPI (4',6-di amidino-2-phenyl indole) (blue).

\begin{tabular}{|l|ll|c|c|}
\hline $\begin{array}{l}\text { Cell } \\
\text { line }\end{array}$ & $\begin{array}{c}\text { histology } \\
\text { /grade }\end{array}$ & aneuploidies & $\begin{array}{c}\text { centrosome } \\
\text { abnormalities }\end{array}$ \\
\hline M162 & OA & I & 0 & 0 \\
\hline G91 & A & II & 0 & 15 \\
\hline G157 & OA & III & 0 & 17 \\
\hline MI4 & GBM IV & 2 & 20 \\
\hline M170 & GBM IV & 4 & 40 \\
\hline G32 & GBM IV & 8 & 40 \\
\hline GI & GC-GBM & 7 & 40 \\
\hline M138 & GBM IV & 5 & 50 \\
\hline MI600 & GBM IV & 4 & 50 \\
\hline MI7 & GC-GBM & 5 & 50 \\
\hline M163 & GBM IV & 9 & 80 \\
\hline GBM & GBM IV & 7 & 90 \\
\hline
\end{tabular}

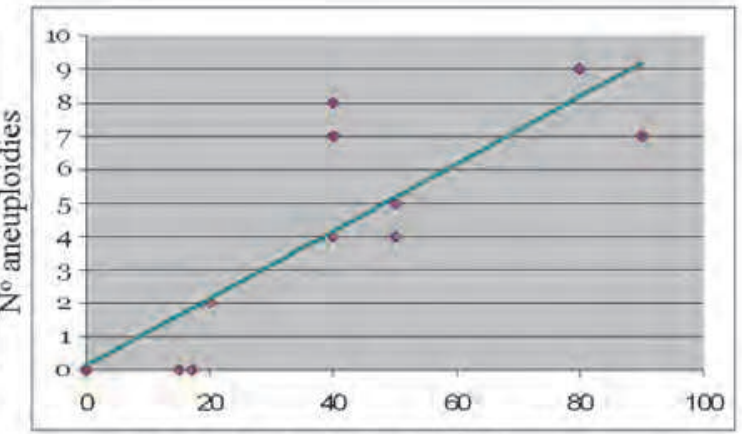

$\mathrm{n}^{\circ}$ cells with aberrant/amplified centrosomes

100 scored cells

$y=0.1006 x+0.1239 \quad R^{2}=0.6805 \quad r=0.82 \quad P=0.001$

Fig. 5. Regression analysis between aneuploidies and centrosome aberrations in glioma cell lines, showing a statistically significant positive correlation. OA: oligoastrocytomas; A: astrocytomas; GBM: glioblastoma multiforme; GC-GBM: giant cell-GBM. 


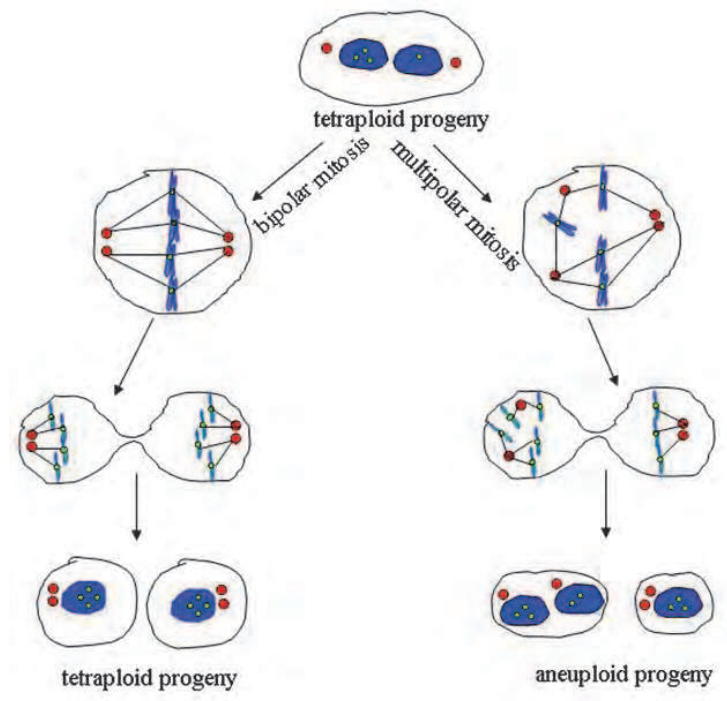

Fig. 6. Fate of a tetraploid cell: if extra centrosomes coalesce, a bipolar spindle assures the progeny maintains a tetraploid set, while lack of this escamotage gives rise to aneuploid progeny through a multipolar mitosis.

Binucleated tetraploid cells with multiple centrosomes are frequently observed in glioma cell lines, as illustrated by a representative image in Figure 7.

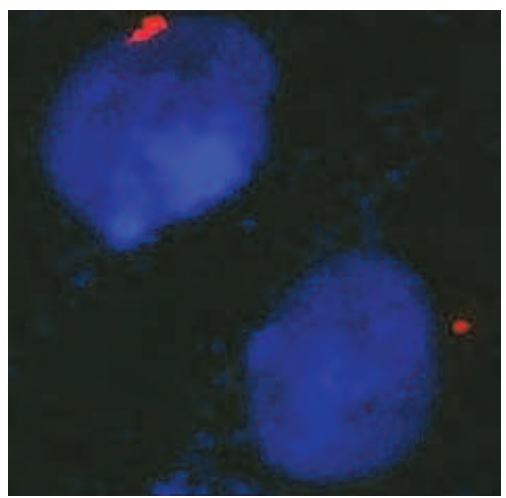

Fig. 7. Immunofluorescence with anti- $\gamma$ tubulin antibody (red) of a binucleated, tetraploidderived glioblastoma cell line, showing coalesced centrosomes in one (left) of the two nuclei. Nuclei are counterstained with DAPI (blue).

To measure the occurrence of DNA damage in once-divided binucleated (BN) cells, the cytokinesis-block micronucleus cytome (CBMN Cyt) assay, an established biomarker to detect spontaneous genomic instability (Fenech, 2007), can be used. Application of CBMN Cyt to a series of glioma cell lines evidenced a high rate of micronuclei (MNi), a biomarker of chromosome breakage and/or whole chromosome loss, and chromosome aberrations 
such as nucleoplasmic bridges (NPBs), a biomarker of DNA misrepair and/or telomere endfusions determining the furrow regression, and nuclear buds (NBUDSs), a biomarker of elimination of amplified DNA and/or DNA repair complexes (Figure 8a, b).

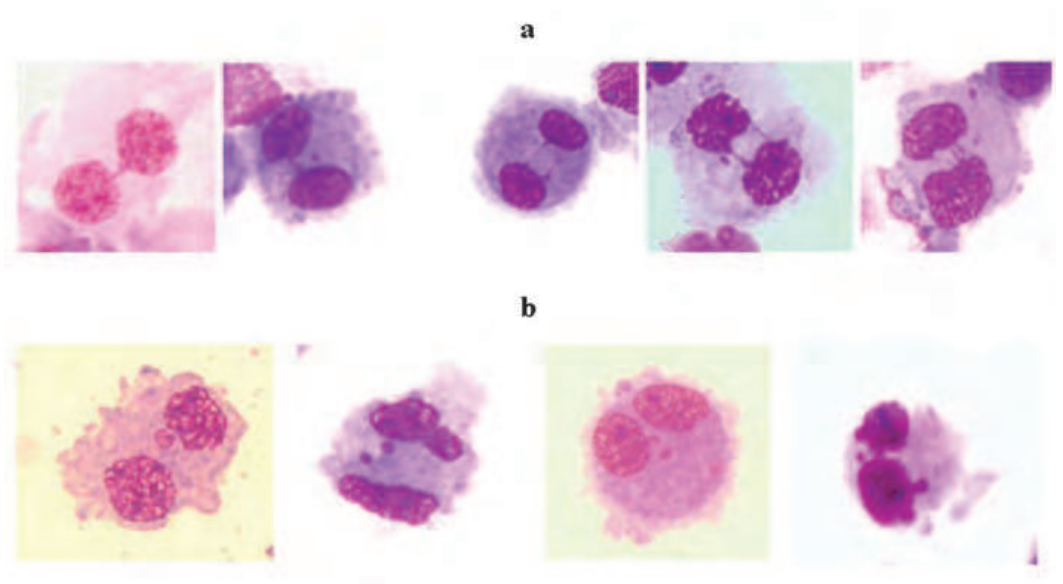

Fig. 8. Photomicrographs of glioma cell lines showing (a) typical binucleated cells with nucleoplasmic bridges and (b) binucleated cells with micronuclei and nuclear buds.

Thus, binucleated tetraploid cells may be transmitted to the progeny and enhance subsequent rounds of aberrant mitosis.

\section{Cytogenomics of gliomas}

Chromosomal instability can be detected by different techniques, including conventional karyotyping, fluorescence in situ hybridization (FISH), spectral karyotyping (SKY) and array-based comparative genomic hybridization (aCGH) analyses.

The classic assay to monitor and quantify chromosome aberrations is karyotyping (see Figure 2).

The in situ hybridization technique with fluorescently labelled probes targeting specific chromosomes is commonly applied on fixed glioma cells, allowing the analysis of chromosomes of interest cell by cell. Examples of FISH analysis in glioma cell lines are shown in Figure 9.

Aneuploidies are rapidly detectable by interphase FISH as well as by quantification of micronuclei formed by chromosomes that lagged behind during a previous mitosis (Figure $10)$.

The technique of array-CGH is considered the most powerful tool for identifying copy number changes of genetic material, since it combines high resolution and large scale genomic analysis, characteristics that are not combined by conventional approaches. Since it allows a quantification of amplifications and deletions, pointing through human genome databases directly to the affected genes, aCGH technology is more and more used in the study of tumours for the identification of potentially causative cancer genes. 

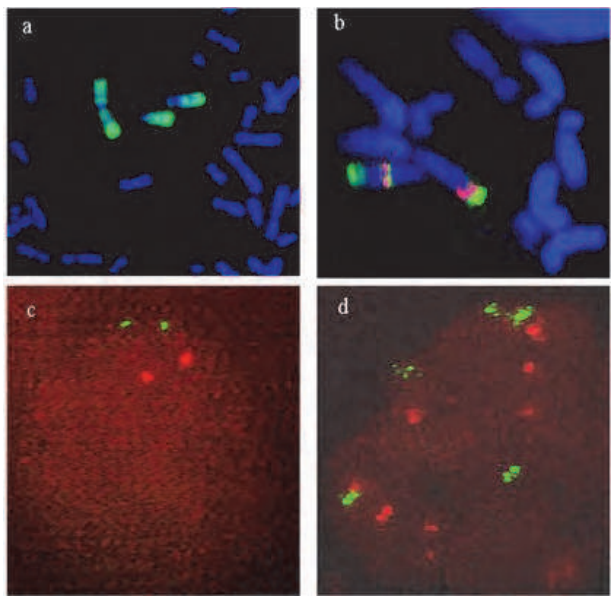

Fig. 9. Partial karyotype of MI-4 GBM cell line displaying chromosome 1 alterations by (a) whole chromosome 1 painting probe and (b) dual colour FISH of YACs 745h6, spanning the 1p36.3 breakpoint (green), and 957f12, mapping to 1p36.1 (red), showing a transposition of 1p36.1 material to der (1)(p22). DNA is counterstained with DAPI (blue). Interphase dual colour FISH of RP11-111p21, mapping to 3p21 control clone (red), and RP11-172g5, mapping to 3q26.3 (green), (c) in a normal diploid cell and (d) in MI-60 GBM cell line showing amplification of the region targeted by RP22-172g5 (green).

a

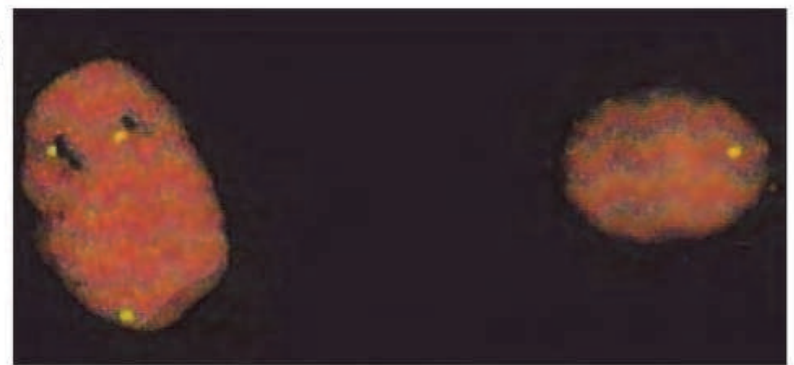

b

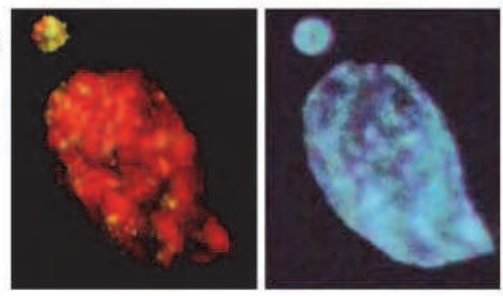

Fig. 10. (a) Interphase FISH with centromeric probes of chromosomes 7 and 10 showing trisomy of chromosome 7 and monosomy of chromosome 10 in MI-4 GBM cell line. (b) Interphase FISH with whole chromosome 19 painting probe showing a micronucleus labelled by chromosome 19 material. DNA is counterstained with DAPI (blue). 
aCGH studies have been applied to gliomas and have successfully complemented previously published metaphase-CGH, SKY and LOH (loss of heterozigosity) analyses (Bredel et al, 2005; Cowell et al., 2004a, 2004b; Kitange et al., 2005; Nigro et al., 2005). Integration of the results has demonstrated an excellent correlation between the findings obtained through this genomic approach and those obtained by alternative techniques, stressing the usefulness and overall accuracy of aCGH as compared to classic previously widely employed analyses (Cowell et al., 2004a, 2004b). Comparative analysis of elaborated aCGH data led to identify copy number changes shared by various glioma grades as well as aberrations apparently related to progression to glioblastoma (GBM) (Roversi et al., 2006).

\section{Non-random chromosomal aberrations in gliomas: The $19 q 13$ abnormalities}

Over the last decade, molecular approaches including mutation screening, LOH and aCGH analyses have led to identify the most frequently recurring genomic imbalances associated with each WHO glioma subtype (Kitange et al., 2005; Koschny et al., 2002; Shapiro, 2002) and hence the driver genes acting in pathways involved in glioma development, either in the initiation stages (Tp53 and Ras by PDGF-NF1) or in malignant progression (Rb-CDKN2CDK4) (Collins, 2004; Zhu \& Parada, 2002). Comprehensive genomic characterization by integrative analysis of DNA copy number, gene expression and DNA methylation aberrations in $>200$ glioblastomas has then refined the definition of human glioblastoma genes and core pathways (The Cancer Genome Atlas [TGCA] Research Network, 2008). Deletion of chromosome $19 q$ is nevertheless of particular interest, as it is shared by all three glioma subtypes, occurring in approximately $75 \%$ of oligodendrogliomas, $45 \%$ of mixed oligoastrocytomas and $40 \%$ of astrocytomas (von Deimling et al., 1992, 1994), where it is associated with the transition from low-grade to anaplastic tumours (Ohgaki et al., 1995; Ritland et al., 1995; Smith et al., 1999) (Box 2).

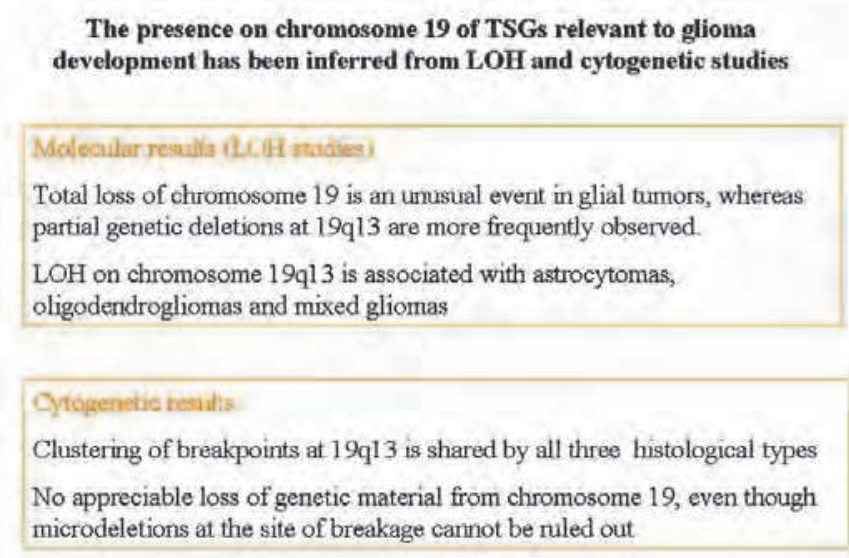

Box 2. TSGs: tumour suppressor genes.

At the cytogenetic level, chromosome $19 \mathrm{q}$ abnormalities are more frequently detectable in GBM than in low grade glioma, with $19 \mathrm{q} 13$ as the most affected region, as shown in Table1. 


\begin{tabular}{|c|c|c|}
\hline Case no. & Diagnosis & Partial Karyotypes \\
\hline D-245 & GBM & $49, X Y, \ldots+19$ \\
\hline D-250 & GBM & $47, X Y, \ldots+19$ \\
\hline D-256 & GBM & $44, X Y, \ldots t(9 ; 19)(p 13 ; q 13) *$ \\
\hline D-290 & GBM & $45, X,-X, \ldots(1 ; ; 19)(q 21 ; q 13) *$ \\
\hline D-299 & GBM & $46, X Y, \ldots$ der(19)t(17,19)(q11:q13)* \\
\hline D-304 & AMG & $43, X Y, \ldots-19$ \\
\hline D-316 & GBM & $46, X X, \ldots \operatorname{der}(19) t(10 ; 19)(q 11 ; q 11)$ \\
\hline D-340 & GBM & $\begin{array}{l}66 \sim 77, X X Y Y, \ldots-19,-19, \operatorname{der}(11) t(11 q 19 p) \times 2 \\
\text { der(11)t(11p19q),der(11)t(11:19)(cen;q13)k }\end{array}$ \\
\hline D-320 & GBM & $47, X X, \ldots$ der(19)t(5;10;19)(q15-21;q11-26;q13) $k$ \\
\hline $\mathrm{nr}$ & GBM & $47, X X \ldots$ der(19)t(19; ?)(q13;?)* \\
\hline $\mathrm{nr}$ & GBM & $79 \sim 83 . Y, \ldots-19,-19, \operatorname{der}(19) t(19: ?)(q 13.3: ?) \times 2 *$ \\
\hline 37 & $\mathrm{PA}$ & $46, \ldots$ der(19)t(19;?)(q13.1,?),der(19)t(19:?)(p13.3:?)-k \\
\hline 43 & $\mathrm{O}$ & $83 \sim 88, X X Y Y, \ldots-19, \operatorname{der}(19) t(19 ; ?)(q 13.3: ?) k$ \\
\hline $\mathrm{nr}$ & GBM & $39 \sim 45, \operatorname{der}(X) t(X ; ?), \ldots . \operatorname{der}(19) t(19 ; ?)(\mathrm{p} 13 ; ?)$ \\
\hline 39 & GBM & $43, X,-X, \ldots$ tdic $(19 ; 22)(p 13.3 ; q 13) k$ \\
\hline 33 & GBM & $43, x \times, \ldots+19$ \\
\hline 36 & GBM & $44, X Y, \ldots$ der(19)t(9;19)(q13;q13)k \\
\hline 37 & GBM & $47 \sim 48, X Y, \ldots+19$ \\
\hline 40 & AA & $65 \sim 75, X Y, \ldots+19,+19$ \\
\hline 34 & GBM & $44, X X, \ldots . \operatorname{der}(19) t(12 ; 19)(q 13 ; q 13) *$ \\
\hline $\mathrm{nr}$ & GBM & $82 \sim 90, \ldots . \operatorname{del}(19)(q 13.1) \ngtr$ \\
\hline $5 \mathrm{MI}$ & AA & $80 \sim 86, \mathrm{XXXX}, \ldots+19$ \\
\hline $85 \mathrm{SI}$ & AA & $48, X Y \ldots \ldots+19$ \\
\hline $56 \mathrm{AW}$ & GBM & $47, X Y, \ldots+19$ \\
\hline $\mathrm{MI} \cdot 4$ & GBM & $47, X X, \ldots \operatorname{der}(1) t(1 ; 19)(p 10, q 10)$ \\
\hline MI-32 & GBM & $47, \mathrm{XX}, \ldots \operatorname{del}(19)(\mathrm{q} 13.2) *$ \\
\hline MI-14 & GBM & $86 \sim 89, X,-X, \ldots,-19,-19$ \\
\hline nr & $\mathrm{O}$ & $45, X Y, \ldots$ der(1)t(1;19)(p11,q11) \\
\hline$T-60$ & GBM & $45 \sim 46, X X, \ldots-19, \operatorname{der}(19)+(19: ?)$ \\
\hline $3 / \mathrm{T} 110$ & $\mathrm{AO}$ & $44 \sim 46, X Y, \ldots-19$ \\
\hline $26 / G 227$ & GBM & $44 \sim 45, X,-Y \ldots \operatorname{der}(19) t(14 ; 19)(q 11.2 ; p 13.1)$ \\
\hline $31 / \mathrm{T} 35$ & GBM & $41 \sim 45, X Y, \ldots . \operatorname{der}(19) t(14 ; 19)(q 13: q 13.1) *$ \\
\hline $36 / \mathrm{T} 66$ & GBM & $48 \sim 52, X Y \ldots$ der(19)t(1;19)(q21:q13)tk \\
\hline $\mathrm{nr}$ & PXA & $46, X Y, \ldots t(1 ; 11 ; 19)(q 24 ; q 23 ; q 13) * k$ \\
\hline 2 & GBM & $44, X X, \ldots t(1 ; 19)(q 23 ; q 13 k k$ \\
\hline nr & GBM & $\ldots t(10 ; 19)(q 24 ; q 13)$ \\
\hline
\end{tabular}

Table 1. Cytogenetic alterations of chromosome 19 in gliomas; 19q13 alterations are marked by red stars. GBM: glioblastoma multiforme; AMG: anaplastic mixed glioma; PA: pilocytic astrocytoma; O: oligodendroglioma; AA: anaplastic astrocytoma; AO: anaplastic oligodendroglioma; PXA: pleomorphic xanthoastrocytoma; nr: not reported. 
Furthermore, similarly to oligodendroglioma, combined LOH of $1 p$ and $19 q$ was found to define a small subset of GBM patients with a significantly better survival, even if their tumours were not morphologically distinguishable from the bulk of GBMs (Schmidt et al., 2002). This finding has been translated into significant advance in the prognosis and treatment of oligodendrogliomas (van den Bent, 2004). A candidate tumour suppressor region has been assigned by $\mathrm{LOH}$ to $19 \mathrm{q} 13.3$ (Hartmann et al., 2002), but no positional or functional candidate gene in this band has yet been appointed.

Only recently an integrated analysis of human glioblastoma multiforme with the application of next generation sequencing technology disclosed a new marker associated with an increase in overall survival, represented by recurrent mutations in the active site of isocitrate dehydrogenase 1 (IDH1) in a large fraction of young patients with secondary GBM (Parsons et al., 2008).

\section{Identification of MARK4 gene through refined FISH mapping of $19 q 13$ breakpoints}

FISH studies of structural 19q chromosomal rearrangements in glioma (Magnani et al., 1999) and a detailed analysis of the breakpoints underlying the $19 \mathrm{q} 13$ alterations in the MI- 4 glioblastoma cell line, led to identify a 19q13.2 intrachromosomal duplication of the $\mathrm{MAP} /$ microtubule affinity-regulating kinase 4 (MARK4) gene (Beghini et al., 2003) (Figure 11). Genomic profiling by means of array-CGH interrogation of 25 primary glioma cell lines including the MI-4 GBM cell line (Roversi et al., 2006) revealed that the BAC clone encompassing MARK4 at 19q13.2 (Figure 12) is included in a "gain" region in a few of the tested cell lines and confirmed MARK4 duplication in the MI-4 glioblastoma cell line (Figure 13).

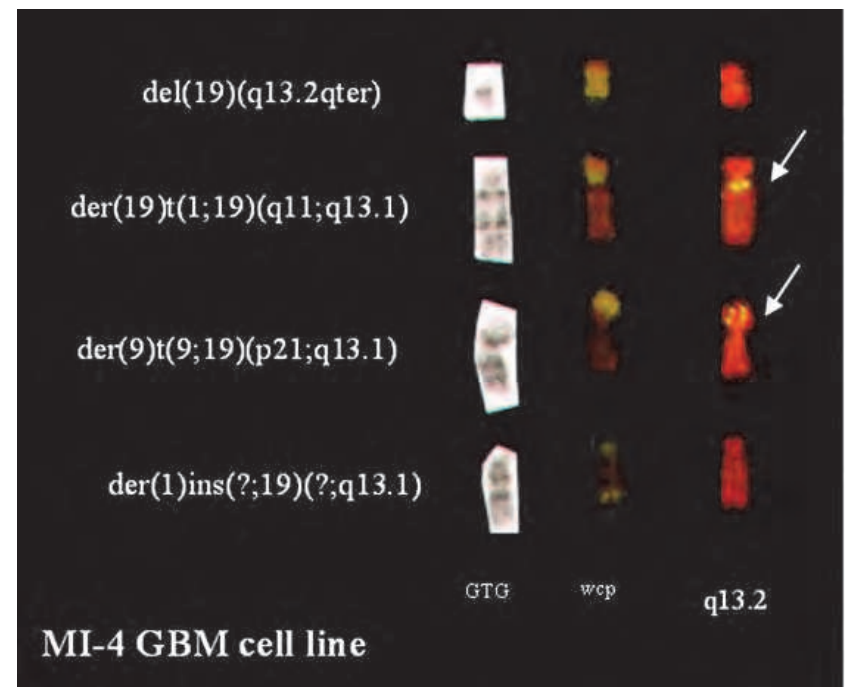

Fig. 11. 19q13.2 intrachromosomal duplication of MARK4 in the MI-4 GBM cell line detected by G-banding and FISH analysis using a whole chromosome painting 19 probe and a MARK4-specific cosmid clone. 


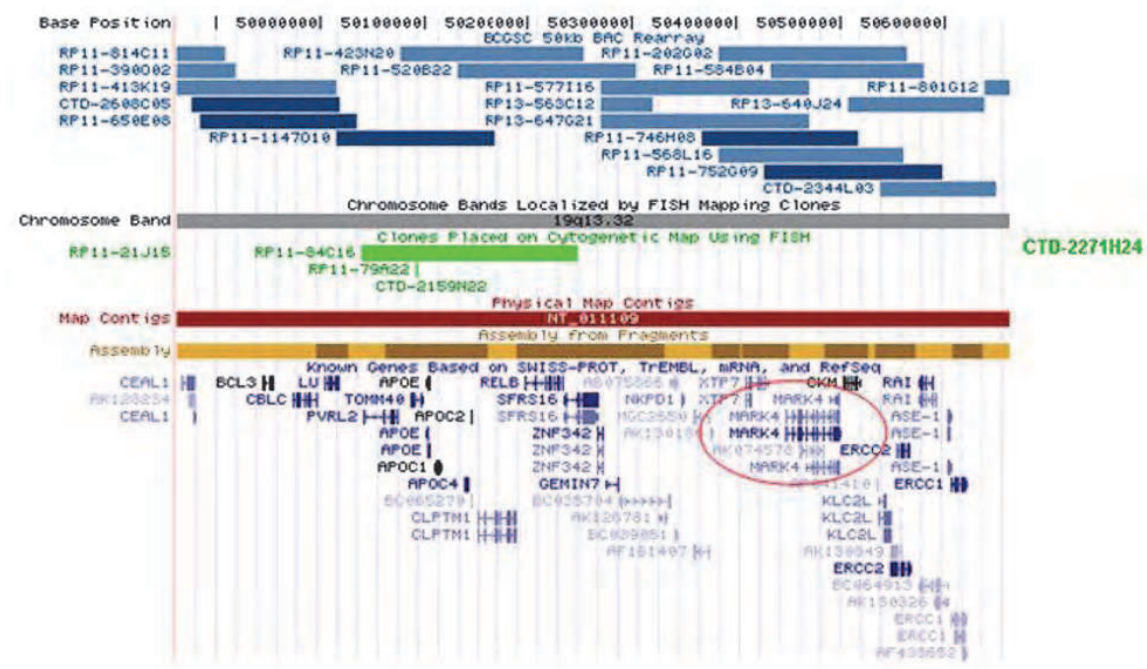

Fig. 12. MARK4 genomic region (http://genome.ucsc.edu/). Clones of chromosome 19q full coverage (blue) overlapping MARK4 gene are circled in red: the gene is entirely encompassed by BAC clones RP11-746H08, RP11-568L16, RP11-202G02, RP11-752G09 RP11584B04, RP13-647G21 and partially encompassed by RP11-577I16.

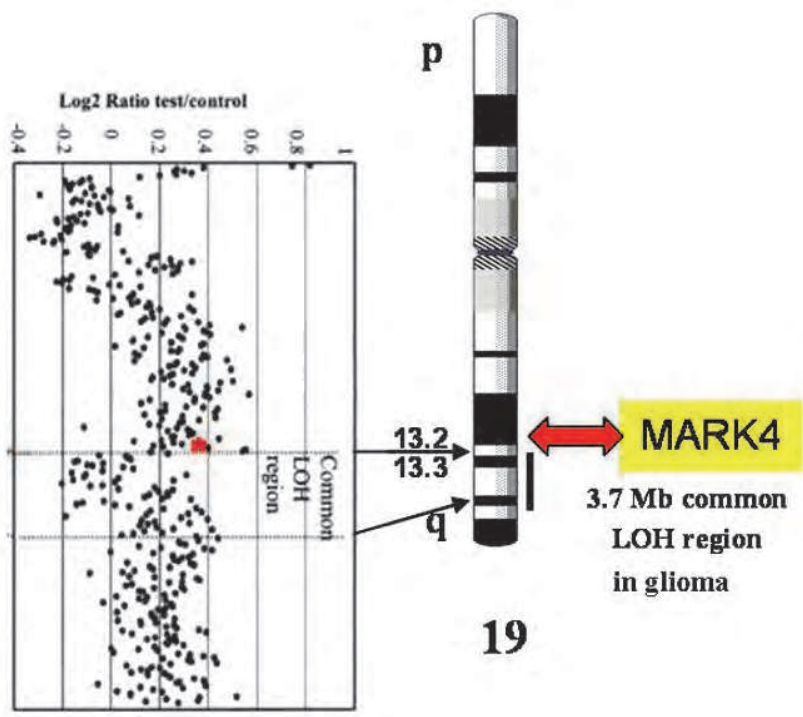

Fig. 13. (left) Chromosome 19q array-CGH of MI-4 GBM cell line, showing duplicated $M A R K 4$ gene (red star) and the common $\mathrm{LOH}$ region in glioma. (right) Schematic representation of MARK4 position on chromosome 19, at the boundary of 19q13.3 LOH region. 
The combined FISH and array-CGH results provided the rationale for investigating a possible role of the serine-threonine kinase MARK4 in glioma. It's worth of note that this gene, belonging to the so called "kinome", maps at the centromeric boundary of the 19q13.3 $\mathrm{LOH}$ region in glioma.

\section{The family of MARK kinases}

MARK4 (MAP/microtubule affinity-regulating kinase 4) is a member of the MARKs family, constituted in mammals by four serine-threonine kinases (MARK1-4) which are able to phosphorylate the microtubule-associated proteins (MAPs, including Tau, MAP2, MAP4 and doublecortin) (Drewes et al., 1997). Microtubules (MTs) are cytoskeleton cylindrical structures formed by a and $\beta$ tubulin dimers; dimers can quickly assemble or disassemble, causing the microtubules to grow or shorten and making them very dynamic. MAPs association stabilizes the MTs; when MARK kinases link a phosphate group to MAPs (phosphorylation), MAPs cannot associate to MTs any longer, thus microtubules become more instable and disassemble (Figure 14).

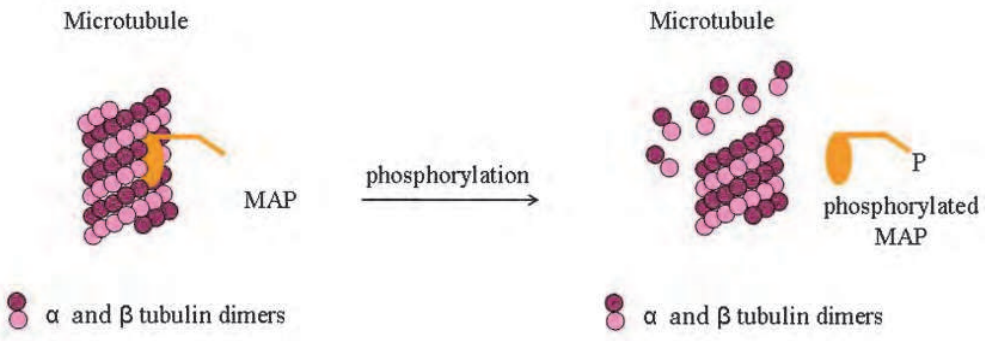

Fig. 14. Schematic representation of microtubules. Assembled $\alpha$ and $\beta$ tubulin dimers form the microtubules, stabilized by MAP association. When MAPs are phosphorylated, they are no more able to bind microtubules, which disassemble.

\subsection{MARKs protein structure}

All MARK proteins have a very conserved structure, consisting of six sequence segments (Marx et al., 2010) (Figure 15):

- the N-terminal header, whose role is unknown;

- the catalytic or kinase domain, containing both the activation/inactivation loop (MARK kinases are in turn activated/inactivated by phosphorylation/dephosphorylation) and the catalytic loop, by which MARKs transfer a phosphate group to substrate proteins;

- a linker, that is a highly and negatively charged motif resembling the common docking (CD) site in MAP kinases; it may bind interactors;

- the UBA domain, a small globular domain with sequence homology to ubiquitinassociated proteins; it may exert an autoregulatory function through interaction with the catalytic domain;

- $\quad$ a spacer, the most variable region among MARK members; it is probably important for regulating MARK activity since it holds phosphorylation sites;

- the C-terminal tail, consisting of the kinase-associated (KA1) domain, whose function is still uncertain. It is characterized by a hydrophobic portion surrounded by positively 
charged residues, which may interact with negatively charged regions of cytoskeletal proteins, MARK catalytic domain or MARK CD domain (Tochio et al., 2006) with an inhibitory effect. It has been proposed it could be involved in protein localization to the membrane, being identified as a domain that binds membrane anionic phospholipids, in particular phosphatidylserine (Moravcevic et al., 2010).

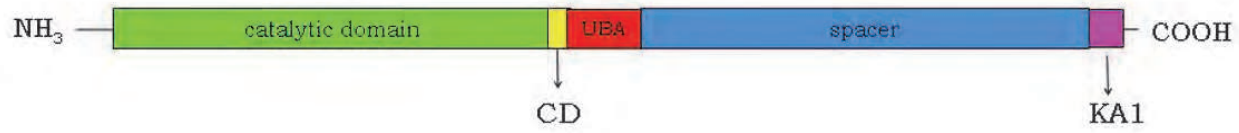

Fig. 15. Schematic representation of MARK protein structure. Boxes are not drawn to scale.

\subsection{MARKs regulation}

Being composed of several domains, MARK proteins are regulated by multiple mechanisms. All MARKs are activated by liver kinase B (LKB1) and MARK kinase (MARKK) by phosphorylation on the threonine residue in the activation loop (Timm et al., 2008); in addition, phosphorylation by CaMKI (calcium/calmodulin-dependent protein kinase I) activates MARK2 (Matenia \& Mandelkow, 2009). On the contrary, phosphorylation by the glycogen synthase kinase $3 \beta$ (GSK3 $\beta$ ) on the serine residue in the activation loop, by aPKC (atypical protein kinase C) in the spacer region or by Pim1 kinase, down-regulates MARK activity (Matenia \& Mandelkow, 2009; Timm et al., 2008). Finally, interaction between MARK catalytic domain and other proteins/MARK domains (such as 14-3-3 proteins, PAK5, MARK UBA and KA1 domains) inhibits MARK activity (Marx et al., 2010).

\subsection{MARKs functions}

Since MARK kinases regulate the affinity between MAPs and MTs, they are implicated in several cellular processes involving the microtubules, such as cytoskeleton dynamics, neuron motility (Schaar et al., 2004), and microtubule-dependent transport of proteins, vesicles and organelles (Mandelkow et al., 2004). Microtubules also play an important role in centrosome formation (Box 3) and in the correct distribution of the chromosomes in the two daughter cells during cell division (mitosis and cytokinesis; Box 4).

Tau is a microtubule-associated protein particularly expressed in the central nervous system. The aggregation of hyperphosphorylated Tau has been demonstrated to form insoluble neurofibrillary tangles (Chin et al., 2000; Gamblin et al., 2003) which are characteristic of Alzheimer's disease. MARKs role in this pathology has been evaluated in many studies, demonstrating, as an example, MARK co-localization with neurofibrillary tangles (Chin et al., 2000).

MARK2 is involved in establishing cell polarity, cooperating in the organization of the epithelial structure of liver, kidney and stomach (Cohen et al., 2004; Matenia \& Mandelkow, 2009), and regulating axon formation in neuronal cells (Chen et al., 2006). Experiments in mice demonstrated that MARK2 is also implicated in many physiological functions, such as fertility, homeostasis of the immune system, memory, growth and metabolism (Bessone et al., 1999; Hurov et al., 2001; Hurov \& Piwnica-Worms, 2007; Segu et al., 2008). MARK3 plays an important role in cell signaling and cell cycle control: phosphorylation of some proteins by MARK3 induces their binding to 14-3-3 proteins thus regulating many cellular pathways (Bachmann et al., 2004; Müller et al., 2001). 


\section{MARK4}

MARK4 is the less characterized member among MARK proteins. It has been discovered by Kato and colleagues in 2001 among a few genes whose expression resulted significantly increased in hepatocarcinoma cells with elevated $\beta$-catenin levels in their nucleus (Kato et al., 2001).

MARK4 gene is located on chromosome 19q13.2, consists of 18 exons and encodes at least two isoforms, namely MARK4S and MARK4L, originated by alternative splicing (Kato et al., 2001) (Figure 16). mRNA splicing is a complex process consisting in the removal of introns, which are non-coding sequences, and in the joining of exons, the coding sequences, to generate the "edited" mRNA ready to be translated into a protein.

- MARK4S ("short") protein is the native isoform, consisting of all the 18 exons, and is 688 aminoacid-long with predicted molecular weight of 75.3 kilo Daltons (kDa);

- MARK4L protein derives from skipping of exon 16, which causes a shift of the reading frame ${ }^{1}$ with a downstream stop codon, originating a longer protein (752 aminoacids; predicted molecular weight: $82.5 \mathrm{kDa}$ ).
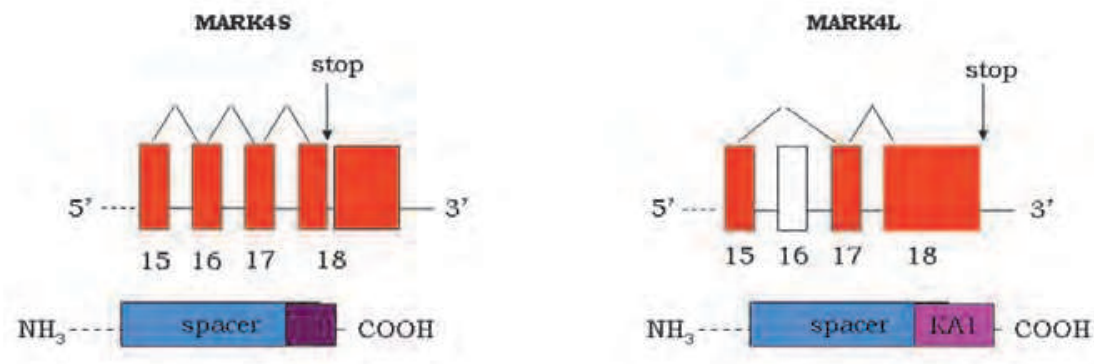

Fig. 16. Alternative splicing of exon 16 gives origin to MARK4 isoforms. When exon 16 is included in the mRNA, the stop codon is inside exon 18 and the encoded protein, MARK4S, lacks the KA1 domain at the C-terminal tail (left); when exon 16 is skipped, a shift of the reading frame occurs, changing the stop codon and generating a longer MARK4L protein, which has the classical KA1 domain (right).

Both MARK4L and S share the same protein structure of MARKs, with 90\% sequence homology in the kinase domain. The two isoforms differ in the C-terminal tail, since MARK4L includes the kinase-associated 1 domain as the other MARK proteins, whereas MARK4S contains a domain with no homology to any known structure (Kato et al., 2001; Moroni et al., 2006) (Figure 16). Actually, MARK4 has less sequence homology in the Cterminus compared to the other MARKs; nevertheless MARK4L tail seems to fold in a similar shape, suggesting that the role of the C-terminal region may apply also to MARK4L (Marx et al., 2010).

\footnotetext{
${ }^{1}$ The mRNA sequence is "read" by an enzyme which matches a determinate "codon", made by three nucleotides, with its respective aminoacid. There are two particular codons, namely the start and the stop codon, which mark the beginning and the end of the protein.
} 


\subsection{MARK4 regulation}

Phosphorylation by LKB1, in the activation loop, activates MARK4, while polyubiquitination of MARK4 inhibits the kinase activation (Al-Hakim et al., 2008). Furthermore, as MARK4 interacts with aPKC (Brajenovic et al., 2008), it could be phosphorylated and inactivated by this kinase as reported for MARK2 and MARK3.

\subsection{MARK4 interactors and hypothetical functions}

By tandem affinity purification and immunoprecipitation experiments, near twenty proteins have been identified as putative MARK4 interactors (Brajenovic et al., 2008). Among them, PKC $\lambda$ and Cdc42 are implicated in cell polarity control and TGF $\beta I A F$ (transforming growth factor $\beta$-inducing anti-apoptotic factor) is thought to be a hortologue of Miranda, a protein involved in the asymmetric division of neuroblasts in Drosophila. MARK4 interacts with the 14-3-3n isoform (Angrand et al., 2006; Brajenovic et al., 2008) of 14-3-3 proteins, which control multiple cellular processes by binding phosphorylated proteins and could directly regulate MARK4 or act as bridges among different pathways. Other MARK4 interactors are ARHGEF2, a cytoskeleton binding protein, and Phosphatase 2A, which is associated to microtubules and regulates Tau (Brajenovic et al., 2008). MARK4 protein has been also found to co-localize and co-precipitate in complex with $\alpha, \beta$, and $\gamma$ tubulin, myosin and actin (Brajenovic et al., 2008; Trinczek et al., 2004).

As the other MARK members, MARK4 phosphorylates MAPs, increasing microtubule dynamics; therefore, as also suggested by the interactions above reported, MARK4 may be involved in many processes involving microtubules, such as cytoskeleton dynamics.

\section{Up-regulation of MARK4L in glioma}

MARK4 gene is expressed ubiquitously in human tissues, with particularly elevated levels in brain and testis (Kato et al., 2001).

Few MARK4 expression studies are reported in literature; they were performed with nonquantitative methods, such as northern blot (Kato et al., 2001; Schneider et al., 2004; Trinczek et al., 2004) and semi-quantitative competitive PCR (polymerase chain reaction) (Moroni et al., 2006), on different organisms (human, rat and mouse tissues) not always allowing to discern between the two MARK4 isoforms. MARK4 transcriptional variants are differentially regulated in human tissues, especially in the central nervous system: MARK4S is the predominant isoform in mouse and human brain, while MARK4L has been found highly expressed in neural progenitors and in gliomas (Beghini et al., 2003; Moroni et al., 2006).

By a semi-quantitative approach MARK4L has been found up-regulated in glioma tissue samples (fragments of glial tumours excised from patients) and glioma cell lines, of different malignancy grades, including the MI-4 GBM cell line carrying the MARK4 duplicated gene as detected by FISH and aCGH analysis. MARK4L has been also found highly expressed in neural progenitors and down-regulated during their glial differentiation into astrocytes, suggesting that it might be necessary for proliferation, being thus highly enriched in proliferating or undifferentiated cells (Beghini et al., 2003) (Figure 17).

Protein kinase activation, often caused by gene amplification and/or mutation, is frequently associated to cancer initiation and progression, as most kinases are involved in cell proliferation. Although array-CGH analyses on glioma cell lines showed that the BAC clone encompassing MARK4 at 19q13.2 is included in a "gain" region in a few of the tested cell 
lines, it did not evidence MARK4 copy number variations, except for the MI-4 GBM cell line (Roversi et al., 2006). Only a few MARK4 alterations are reported in the literature, namely two missense mutations (aminoacidic substitution) in exon 12 (R377Q and R418C in the spacer region), two silent mutations (no aminoacidic substitution) in exons 5 (Y137Y) and 9 (I286I) (kinase domain), while one intronic mutation (exon $8+5 \mathrm{C}>\mathrm{T}$; kinase domain) has been found in a few tumour samples (Greenman et al., 2007). In addition, only a splice-site mutation (exon $13+1 \mathrm{G}>\mathrm{A}$; spacer region) has been identified in one among 91 glioblastoma samples (TGCA Research Network, 2008). However, CpG methylation and/or promoter amplification have not yet been investigated. Based on this evidence, neither amplification nor mutations of MARK4 gene seem to be the cause of its reported sustained expression in glioma samples.

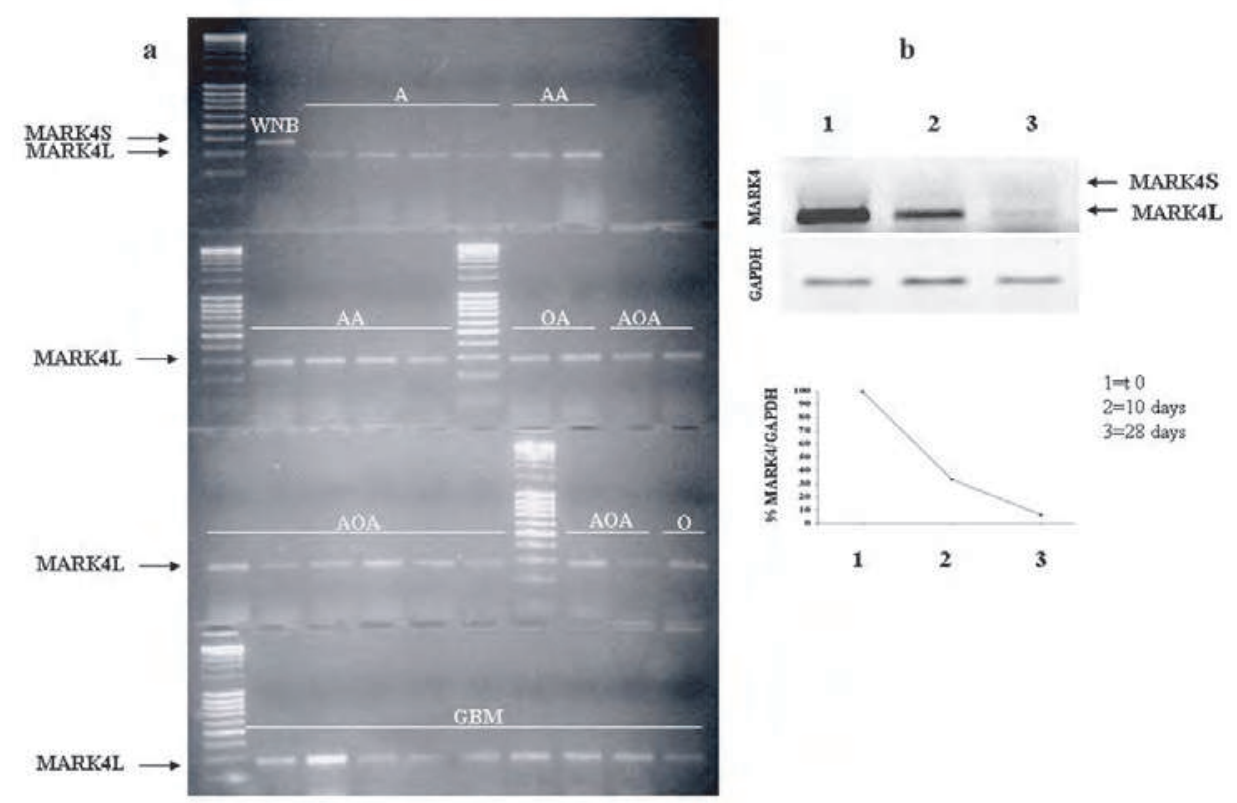

Fig. 17. (a) Semi-quantitative Reverse Transcription-PCR of MARK4S and MARK4L isoforms in whole normal brain (WNB) and in 32 glioma cell lines, subdivided according to WHO grade (A: astrocytoma; AA: anaplastic astrocytoma; OA: oligoastroctytoma; AOA: anaplastic oligoastrocytoma; O: oligodendroglioma; GBM: glioblastoma multiforme). (b) Downregulation of MARK4L expression during glial differentiation of human neural progenitors: semi-quantitative RT-PCR (top) and graph representation (bottom) of MARK4L expression in neural progenitors at times 0,10 and 28 days of induced differentiation.

\section{MARK4 sub-cellular localization in glioma cell lines}

Recently, immunofluorescence analyses with a specific anti-MARK4L antibody highlighted multiple sub-cellular localizations for the endogenous MARK4L protein in glioma cell lines (Magnani et al., 2009). 


\subsection{Centrosome localization}

It has been assessed that, under microtubule-stabilizing conditions, MARK4L localizes in the perinuclear region of glioma cell lines. By co-localization experiments with both anti-MARK4L and anti-ytubulin (the main centrosomal protein) antibodies, this perinuclear localization has been demonstrated to correspond to the centrosome (Magnani et al., 2009), as shown in Figure 18 (Box 3). This result confirms previous data referring to exogenous MARK4 protein conjugated to GFP (green fluorescent protein), which has been shown to co-localize with microtubules and centrosomes of $\mathrm{CHO}$ (Chinese hamster ovary) and neuroblastoma cell lines (Trinczek et al., 2004), in contrast to MARK1, MARK2 and MARK3 that exhibit uniform cytoplasmic localization. Furthermore, it has been demonstrated that the association with the centrosome is independent from microtubules, since it is not abolished when microtubules are depolimerized by nocodazole treatment (Magnani et al., 2009).
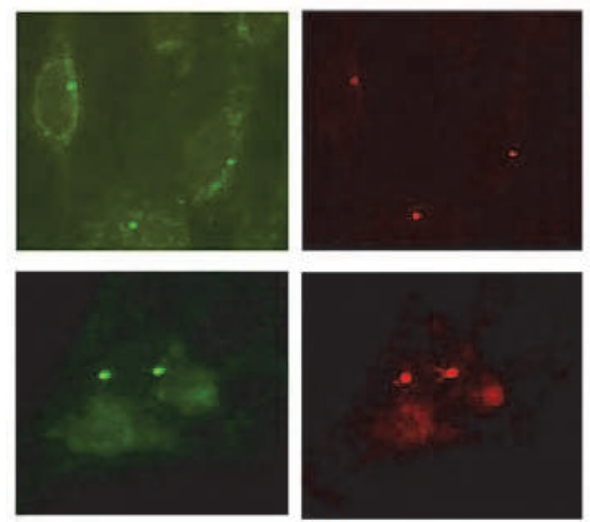

Fig. 18. Anti-MARK4L (green; left) and anti-үtubulin (red; right) antibodies showing colocalization signals in interphase (top) and mitotic (bottom) centrosomes of glioma cell lines.

\footnotetext{
The centrosome

The centrosome is a little organelle, not bound by membrane, positioned centrally in the cell near the nucleus. It is the primary MicroTubule Organizing Center (MTOC), as it can nucleate and organize microtubules. It consists of two distinct domains:

- the centriolar domain, including the centrioles, which are cylindrical organelles important for centrosome organization and replication Each centriole consists of 9 triple microtubules;

- the pericentriolar domain, consisting of many fibers and proteins that surround the centriole. In this domain microtubules are nucleated, by associating $\alpha$ and $\beta$-tubulin dimers from a $\gamma$-tubulin ring (Doxsey, 2001).

The centrosome plays a key role in organizing the interphase cytoskeleton (regulating cell polarity, adhesion and motility) and the mitotic spindle (Kramer et al, 2002). It also contributes to cell cycle progression and cytokinesis (Martinez-Garay et al. 2006) and is involved in cell cycle transitions, in the cellular response to stress and signal transduction (Doxsey et al., 2005). The centrosomes duplicate only once in the cell cycle, during G1/S transition and in $\mathrm{S}$ phase, and form a strictly bipolar spindle during mitosis.
}

Box 3 . 
The endogenous MARK4L localizes both at normal interphase centrosomes (Figure 18) as well as at the aberrant centrosomes frequently observed in glioma cell lines (see Figure 4), suggesting a possible link between the alternatively spliced kinase and the mitotic instability frequently observed in human glioma. Two abnormal centrosome configurations are reported: a random one (multiple centrosomes randomly distributed) and a clustered one (multiple centrosomes collected in a single large aggregate) (Magnani et al., 2009), as depicted in Figure 19.

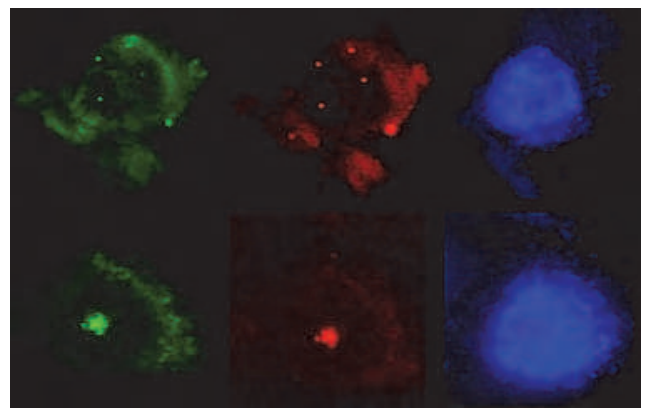

Fig. 19. Anti-MARK4L (green; left) and anti-үtubulin (red; middle) antibodies showing colocalization signals in abnormal centrosomes of glioma cell lines. Both the abnormal centrosome configurations are reported: the random one (top) and the clustered one (bottom). The nuclei are counterstained with DAPI (blue, right).

\subsection{Midbody localization}

The centrosome association is maintained during the entire course of mitosis, as MARK4L co-localizes with ytubulin in all the cell cycle phases. The anti-MARK4L antibody is also detected in the midbody, a microtubule structure forming at the contact point between the two daughter cells at the end of the cell division. These data demonstrate that the kinase is endogenously associated with the centrosomes during the whole cell cycle and concentrates thereafter into the midbody during cytokinesis (Magnani et al., 2009) (Figure 20) (Box 4).

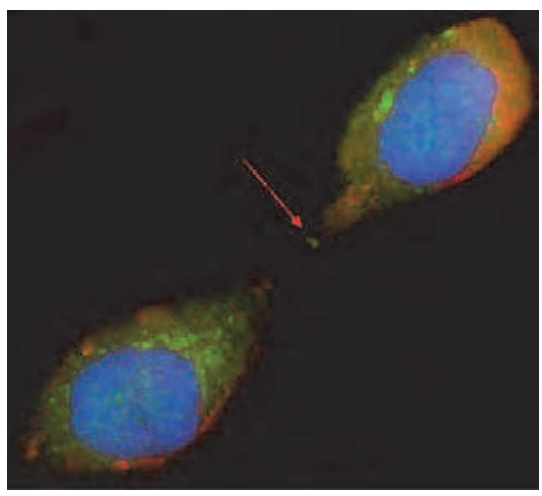

Fig. 20. Co-localization of MARK4L (green) and ytubulin (red) proteins at the midbody (arrow) during the cytokinesis of a glioma cell. The nuclei are counterstained with DAPI (blue). 


\section{Cell cycle, cytokinesis and midbody}

The cell cycle corresponds to the life of a cell, beginning from its formation from a mother cell to its division into two daughter cells or to its death

It consists of two main phases, interphase (subdivided in $\mathrm{G} 1, \mathrm{~S}$ and $\mathrm{G} 2$ phases) and M phase (mitosis+cytokinesis). During interphase the cell grows and doubles its structures and DNA content; during the $\mathrm{M}$ phase the cell splits into two daughter cells.

In mitosis the two centrosomes move to opposite poles in the cell (asters) and organize the mitotic spindle, formed by bundles of microtubules getting off the centrosomes. The spindle binds chromosomes and segregate them toward one aster or the other, splitting the genetic material between the two poles.

During cytokinesis, the mitotic spindle locates the cleavage furrow, which will divide the cell, in a point which is equidistant from the two asters. In this furrow, a contractile ring of actin and myosin grows up and shrinks, causing the "stricture" of the cell, until the two opposing surfaces of the membrane come in contact and merge, closing and delimiting the two daughter cells (Bringmann, 2005).

Initially the two daughter cells are connected by a narrow intercellular bridge, whose core is the midbody, consisting of microtubules and a dense matrix (Mullins \& McIntosh, 1982). The diameter of the intercellular bridge then decreases until it varishes, making the two daughter cells effectively separated. The midbody is finally discarded and undergoes degradation (Mullins \& Biesele, 1977). The midbody is thought to have an important role in maintaining a bipolar spindle and in correctly separating the cytoplasm between the two daughter cells.

Box 4 .

\subsection{Nucleolar localization}

Under standard immunofluorescence conditions, anti-MARK4L antibody is also detected in the nucleoli (Box 5).

Silver-colloid method, which allows visualizing the nucleolar organizing regions (NORs), and co-localization experiments with anti-nucleolin (a nucleolar protein) antibody allowed to assess that the nuclear structures bound by MARK4L antibody are indeed the nucleoli (Magnani et al., 2009) (Figure 21) (Box 5).

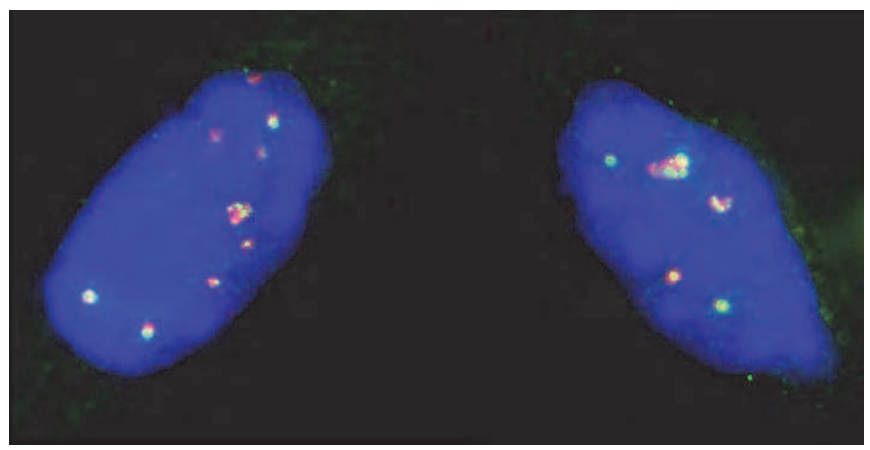

Fig. 21. Co-localization of MARK4L (green) and nucleolin (red) proteins in the nucleoli of glioma cells. The nuclei are counterstained with DAPI (blue). 


\section{The nucleolus}

The nucleolus is a sub-nuclear organelle not surrounded by membranes and whose main function is ribosome biogenesis (ribosomes are involved in protein synthesis). It originates at the end of mitosis from the Nucleolus Organizing Regions (NORs), which are clusters of genes (rDNA), codifying for ribosomal RNA (rRNA), located on the acrocentric chromosomes.

The nucleolus consists of three main components, each with a different role in the formation of ribosomes, here defined starting from the inside of the nucleolus to outside:

- the fibrillar center, which is a NOR (rDNA);

- the dense fibrillar component, consisting of pre-rRNA;

- the granular component, whose granular appearance is conferred by the presence of ribosomal subunits.

The transcription of the rDNA leads to the formation of pre-rRNAs, which then undergo rearrangements and are assembled with ribosomal proteins to form the pre-ribosomes. The pre-ribosomal particles then move into the cytoplasm, passing through the nuclear pores (Carmo-Fonseca et al, 2000; Schwarzacher \& Wachtler, 1983).

Besides this traditional ribosome biogenesis activity, the nucleolus is characterized by multiple functions, including the response to cellular stress, the regulation of cell cycle (Visintin \& Amon, 2000) and cell growth (Zhang et al, 2010) and of post-translational modifications (phosphorylation and sumoylation) of proteins.

Box 5.

The overall immunofluorescence data on endogenous MARK4L protein confirm the previous evidence on its centrosome association and highlight two novel localization sites of MARK4L: the nucleolus and the midbody (Magnani et al., 2009).

Immunoblotting with anti-MARK4L antibody on centrosomes, midbody and nucleoli isolated by biochemical fractionation from glioblastoma cell lines confirmed the presence of MARK4L protein in each fraction, validated by antibodies specific for each cell structure:

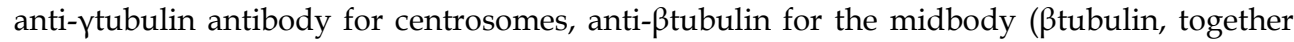
with atubulin, accounts for $30 \%$ of midbody proteins) and anti-nucleolin for the nucleolus (Magnani et al., 2009).

The localization pattern of MARK4L delineated by the above studies suggests that the kinase may take part in cell cycle progression and influence the microtubules, particularly those affecting the centrosome and midbody.

MARK4L association with the nucleolus in glial tumours is very interesting, since MARK4L could have a functional impact on this organelle, being requested for its building and maintenance like other protein kinases, as well as it could be spatially regulated by alternate translocation in and out the nucleolus. Many proteins are indeed sequestered in the nucleolus and then released according to a temporally regulated activity, since they must exert their function in certain phases of the cell cycle (Visintin \& Amon, 2000). Last, the nucleolar localization of a protein may also influence its stability, protecting the protein from proteasomal degradation, since proteasomes are present in the nucleoplasm but not in nucleoli (Wojcik \& DeMartino, 2003). 


\section{Conclusion}

A few remarks can be drawn from the above synthesis on cytogenomics of human gliomas and the MARK4 cell cycle gene as a likely "player" in gliomagenesis.

Gliomas are one of the most intractable tumours due to their "complex identity": as it has been beautifully underlined, the generation - since the earliest glioma stages - of multiple cell populations with different genotypic and phenotypic features makes unlikely to succeed therapeutic strategies targeting only clones with "dominant" or "average" characteristics of the cell population (Noble \& Dietrich, 2004). The intrinsic genomic heterogeneity of human glioma has first been disclosed cytogenetically, as documented by a huge number of studies which across two decades have used the cytogenetic tools suitable to monitor the intratumour cell heterogeneity and to discern "recurrent" and potentially causative chromosomal rearrangements. A few of these rearrangements entered the diagnostic and prognostic flow chart of gliomas, others allowed to identify crucial genes which mutations or imbalance are the signature of a specific glioma type or glioma malignancy stage. In line with a research pathway that has been reiterated for several genes of relevance in cancer, focus on MARK4 has been pinpointed by cytogenetics and deepened by multiple tools ranging from gene-targeted molecular to genomic and cytogenomic analyses. Despite its nature of serine-threonine kinase gene, MARK4 has not be found mutated or affected by copy number alterations in glioma, while its encoded proteins represented by two different isoforms, MARK4S and MARK4L, could be featured as a potential target of dysregulation in tumours due to its dual nature. The latter isoform, produced by alternative splicing, has been found up-regulated in glioma and shown to display sub-cellular localizations, namely the centrosome, the midbody and the nucleolus, which strictly associate it with the process of cell division. Interestingly, alternative mRNA splicing has been considered a mechanism not only increasing proteomic complexity but also involved in cancer, through mechanisms of oncogenes/tumour suppressors activation/inactivation or through the generation of CIN (López-Saavedra \& Herrera, 2010). CIN is a general property of aneuploid cancer cells and is generated by defects in different processes, among which the regulation of the number of centrosomes, the dynamics of microtubules attachment to the kinetochores and the overall control of cell cycle. Defects in centrosomal number and structure have been well documented in gliomas (D'Assoro et al., 2002; Katsetos et al., 2006; Magnani et al., 2009) raising the issue whether the increased MARK4L isoform, a gene involved in microtubule dynamics, may concur to errors in chromosomal segregation driving gliomagenesis.

Recent application of multidimensional technological approaches has comprehensively highlighted the scenario of glioma genes and core pathways. However, despite the impressive advances, the links between genes alteration and cellular behavior are yet hampered by the multiplicity of the genetic lesions and the interconnections among the different affected pathways. Hopefully ongoing and next years research will compose the puzzle promising to translate into the clinical set the unraveled glioma pathomechanisms.

\section{Acknowledgement}

We thank the Associazione italiana per la ricerca sul cancro (AIRC) for supporting this work (grant n 4217 to LL for 2008). 


\section{Methods}

\subsection{Cell cultures and preparation of human metaphase chromosomes}

Glioma cell lines were derived from primary tumour post-surgery specimens and subsequently maintained by serial passages in RPMI 1640 medium containing 5\% Fetal Calf Serum at $37^{\circ} \mathrm{C}$ in a $5 \% \mathrm{CO}_{2}$ atmosphere. Most of the cell lines were used within the first 30 passages.

Metaphase spreads were obtained on both fresh tumours and cultured cell lines, harvested when "peak" mitotic activity was observed; usually, a 16-hour treatment with Colcemid at a final concentration of $0.01-0.02 \mathrm{mg} / \mathrm{ml}$ is employed (Magnani et al., 1994).

\subsection{Fluorescence in situ hybridization (FISH) analysis}

Fluorescence hybridization with genomic DNA has proven to be a powerful tool for identification of chromosome rearrangements in cancer cells. Potential applications include detection of chromosome-specific aneuploidy in metaphase and interphase cells, quantification of the frequency of chromosome translocations and/or aneuploidy as a measure of genetic damage, and detection of diagnostically and prognostically relevant chromosomal lesions. Detection of translocations between human metaphase chromosomes is possible by using cocktails of chromosome-specific sequences that hybridize more or less uniformly along the chromosome. Depending on the aberration, its detection may be by visual fluorescence microscopy (see Figures 9, 10). In brief: slides carrying interphase or metaphase spreads are washed in $2 \times$ SSC $(1 \times$ SSC is $0.15 \mathrm{M} \mathrm{NaCl} / 0.015 \mathrm{M}$ sodium citrate), dehydrated in an ethanol series and denatured $[70 \%$ (vol/vol) formamide/2x SSC (final concentration), $\mathrm{pH} 7$, at $70^{\circ} \mathrm{C}$ for $2 \mathrm{~min}$ ]. The hybridization mix consists of (final concentrations) $50 \%$ formamide, $2 x$ SSC, 20\% dextran sulfate, carrier DNA (sonicated herring sperm DNA), and biotin-labeled human genomic DNA. The mixture is applied to the slides under a glass coverslip. After overnight incubation at $37^{\circ} \mathrm{C}$, the slides are washed at $45^{\circ} \mathrm{C}$ ( $50 \%$ formamide/2x SSC, $\left.\mathrm{pH} 7\right)$, and immersed in $\mathrm{BN}$ buffer (0.1 $\mathrm{M}$ sodium bicarbonate, $0.05 \%$ Nonidet $\mathrm{P}-40, \mathrm{pH}$ ). The slides are never allowed to dry after this step. The coverslips are then removed and fluorescein-avidin DCS is applied. The coverslips are put back in their original places and the slides incubated $20 \mathrm{~min}$ at $37^{\circ} \mathrm{C}$. They are then washed in $\mathrm{BN}$ buffer at $45^{\circ} \mathrm{C}$. The intensity of biotin fluorescence is amplified by adding a layer of biotinylated goat anti-avidin antibody followed, after washing as above, by another layer of fluorescein-avidin DCS. After washing in BN buffer a fluorescence anti-fade solution is added. The DNA counterstain [4,6-diamidino-2-phenylindole (DAPI) or propidium iodide] is included in the anti-fade solution (Magnani et al., 1999; Pinkel et al., 1986).

\subsection{Immunofluorescence}

Immunofluorescence analyses enable to visualize, by fluorescence microscopy, the subcellular localization of a specific protein in cultured cells. The target protein is recognized by an antibody, which in turn is conjugated to a fluorochrome emitting fluorescent light. Briefly, cells are grown on glass chamber slides, then permeabilized (with solvents that extract lipids from the membranes allowing antibodies to reach a sub-cellular structure) and fixed (in order to protect the cell structure from eventual damages and to "freeze" cells in their current state). Afterwards, cells are incubated with bovine serum albumin (BSA) to block non-specific binding of antibodies. Glass slides are then incubated with a primary 
antibody specific to the target protein, then with a secondary antibody conjugated to the fluorochrome and finally observed under the microscope (Magnani et al., 2009).

\subsection{Biochemical fractionation and immunoblotting}

By biochemical fractionation we mean the whole techniques that allow to separate and isolate intact cellular components. It usually consists in carefully breaking the cell membrane with homogenizers and isotonic/hypotonic solutions, so that intact organelles can come out, and in separating cellular components by centrifugation, on the basis of differences in their mass and specific weight. Centrosome, midbody and nucleoli isolation protocols are described in Magnani et al., 2009 and based on methods respectively by Moudjou \& Bornens, 1994; Chu \& Sisken, 1977; Muramatsu et al., 1963. In particular, for midbody isolation cells are synchronized in mitosis by nocodazole treatment and then released from mitotic arrest in nocodazole-free medium, so that after 30 minutes near $90 \%$ of cells had formed the midbody.

After membrane breaking, all the passages are done at $4^{\circ} \mathrm{C}$ and with protease inhibitors, in order to prevent protein degradation, possibly exerted by released proteases. Proteins extracted from centrosome, midbody and nucleolus fractions are then analyzed by immunoblotting. Proteins are first separated, according to their molecular weight, by SDSPAGE (Sodium Dodecyl Sulphate - PolyAcrilamide Gel Electrophoresis): this technique allows proteins to migrate, driven by electric current, in a porous gel, with speed depending exclusively on their size. Afterwards, separated proteins are transferred onto a membrane, incubated with a blocking solution (BSA or milk) to prevent non-specific binding of antibodies and then incubated with appropriate antibodies (immunoblotting). The primary antibody is specific to the target protein and is recognized by the secondary antibody conjugated to HRP (horse radish peroxidase). Antibodies are detected by covering the membrane with a peroxide/enhancer solution, which is oxidized by HRP and emits light signals.

\section{References}

Al-Hakim, A.K.; Zagorska, A.; Chapman, L.; Deak, M.; Peggie, M. \& Alessi, D.R. (2008). Control of AMPK-related kinases by USP9X and atypical Lys ${ }^{29} /$ Lys $^{33}$-linked polyubiquitin chains. The Biochemical Journal, Vol.411, pp. 249-260, ISSN 02646021

Angrand, P.O.; Segura, I.; Völkel, P.; Ghidelli, S.; Terry, R.; Brajenovic, M.; Vintersten, K.; Klein, R.; Superti-Furga, G.; Drewes, G.; Kuster, B.; Bouwmeester, T. \& AckerPalmer, A. (2006). Transgenic mouse proteomics identifies new 14-3-3-associated proteins involved in cytoskeletal rearrangements and cell signaling. Molecular and Cellular Proteomics, Vol.5, No.12, pp. 2211-2227, ISSN 1535-9484

Bachmann, M.; Hennemann, H.; Xing, P.X.; Hoffmann, I. \& Möröy, T. (2004). The oncogenic serine/threonine kinase Pim-1 phosphorylates and inhibits the activity of Cdc25C-associated kinase 1 (C-TAK1): a novel role for Pim-1 at the G2/M cell cycle checkpoint. Journal of Biological Chemistry, Vol. 279, pp. 48319-48328, ISSN 0021-9258 
Basto, R.; Brunk, K.; Vinadogrova, T.; Peel, N.; Franz, A.; Khodjakov, A. \& Raff, J.W. (2008). Centrosome amplification can initiate tumorigenesis in flies. Cell, Vol. 133, pp. 10321042, ISSN 0092-8674

Bayani, J.; Selvarajah, S.; Maire, G.; Vukovic, B.; Al-Romaih, K.; Zielenska, M. \& Squire, J.A. (2007). Genomic mechanisms and measurement of structural and numerical instability in cancer cells. Seminars in Cancer Biology, Vol.17, pp. 5-18, ISSN 1044$579 \mathrm{X}$

Beghini, A.; Magnani, I.; Roversi, G.; Piepoli, T.; Di Terlizzi, S.; Moroni, R.F.; Pollo, B.; Fuhrman Conti, A.M.; Cowell, J.K.; Finocchiaro, G. \& Larizza, L. (2003). The neural progenitor-restricted isoform of the MARK4 gene in 19q13.2 is upregulated in human gliomas and overexpressed in a subset of glioblastoma cell lines. Oncogene, Vol. 22, pp. 2581-2591, ISSN 0950-9232

Bessone, S.; Vidal, F.; Le Bouc, Y.; Epelbaum, J.; Bluet-Pajot, M.T. \& Darmon, M. (1999) EMK protein kinase-null mice: dwarfism and hypofertility associated with alterations in the somatotrope and prolactin pathways. Developmental Biology, Vol. 214, pp. 87101, ISSN 0012-1606

Bigner, S.H.; Mark, J.; Burger, P.C.; Mahaley, M.S.Jr.; Bullard, D.E.; Muhlbaier, L.H. \& Bigner, D.D. (1988). Specific chromosomal abnormalities in malignant human gliomas. Cancer Research, Vol.88, pp. 405-411, ISSN 0008-5472

Brajenovic, M.; Joberty, G.; Küster, B.; Bouwmeester, T. \& Drewes, G. (2004). Comprehensive proteomic analysis of human Par protein complexes reveals an interconnected protein network. The Journal of Biological Chemistry, Vol. 279, No.13, pp. 1280412811, ISSN 1083-351X

Bredel, M.; Bredel, C.; Juric, D.; Harsh, G.R.; Vogel, H.; Recht, L.D. \& Sikic, B.I. (2005). Highresolution genome-wide mapping of genetic alterations in human glial brain tumors. Cancer Research, Vol. 10, pp. 4088-4096, ISSN 0008-5472

Bringmann, H. (2005). Cytokinesis and the spindle midzone. Cell cycle, Vol. 4, No.12, pp. 1709-1712, ISSN 1551-4005

Brinkley, B.R. (2001). Managing the centrosome numbers game: from chaos to stability in cancer cell division. Trends in Cell Biology, Vol.11, pp. 18-21, ISSN 0962-8924

Carmo-Fonseca, M.; Mendes-Soares, L. \& Campos, I. (2000). To be or not to be in the nucleolus. Nature Cell Biology, Vol. 2, No.6, pp. E107-112, ISSN $1097-6256$

Chen, Y.M.; Wang, Q.J.; Hu, H.S.; Yu, P.C.; Zhu, J., Drewes, G.; Piwnica-Worms, H. \& Luo, Z.G. (2006). Microtubule affinity-regulating kinase 2 functions downstream of the PAR-3/PAR-6/atypical PKC complex in regulating hippocampal neuronal polarity. Proceedings of the National Academy of Science of the United States of America, Vol. 103, pp. 8534-8539, ISSN 0027-8424

Chin, J; Knowles, R.B.; Schneider, A.; Drewes, G.; Mandelkow, E.M. \& Hyman, B.T. (2000). Microtubule-Affinity Regulating Kinase (MARK) is tightly associated with neurofibrillary tangles in Alzheimer brain: a fluorescence energy transfer study. Journal of Neuropathology and Experimental Neurology, Vol. 59, No.11, pp. 966-971, ISSN 0022-3069

Chu, L.K. \& Sisken, J.E. (1977). The isolation and preliminary electrophoretic analysis of the mitotic spindle from cultured mammalian cells. Experimental Cell Research, Vol. 107, pp. 71-77, ISSN 0014-4827 
Cimini, D.; Cameron, L.A. \& Salmon, E.D. (2004). Anaphase spindle mechanics prevent missegregation of merotelically oriented chromosomes. Current Biology, Vol. 23, pp. 2149-2155, ISSN 0960-9822

Cohen, D.; Brennwald, P.J.; Rodriguez-Boulan, E. \& Müsch, A. (2004). Mammalian PAR-1 determines epithelial lumen polarity by organizing the microtubule cytoskeleton. Journal of Cell Biology, Vol. 164, pp. 717-727, ISSN 1540-8140

Collins, V.P. (2004). Brain tumours: classification and genes. Journal of Neurology, Neurosurgery \& Psychiatry, Vol. 75, (Suppl 2), pp. 2-11, ISSN 0022-3050

Cowell, J. K.; Barnett, G.H. \& Nowak, N.J. (2004a). Characterization of the 1p/19q chromosomal loss in oligodendrogliomas using comparative genomic hybridization arrays (CGHa). Journal of Neuropathology \& Experimental Neurology, Vol. 63, pp. 151-158, ISSN 0022-3069

Cowell, J.K.; Matsui, S.; Wang, Y.D.; LaDuca, J.; Conroy, J.; McQuaid D. \& Nowak N.J. (2004b). Application of bacterial artificial chromosome array-based comparative genomic hybridization and spectral karyotyping to the analysis of glioblastoma multiforme. Cancer Genetics and Cytogenetics, Vol. 151, pp.36- 51, ISSN 0165-4608

D'Assoro, A.B.; Lingle, W.L. \& Salisbury, J.L. (2002). Centrosome amplification and the development of cancer. Oncogene, Vol. 21, pp. 6146-6153. Review, ISSN 0950-9232

Doxsey, S. (2001). Re-evaluating centrosome function. Nature, Vol.2, No.9, pp. 688-698, ISSN 0028-0836

Doxsey, S.; McCollum, D. \& Theurkauf, W. (2005). Centrosomes in cellular regulation. Annual Review of Cell and Developmental Biology, Vol. 21, pp.411-434, ISSN 10810706

Drewes, G.; Ebneth, A.; Preuss, U.; Mandelkow, E.M. \& Mandelkow, E. (1997). MARK, a novel family of protein kinases that phosphorylate microtubule-associated proteins and trigger microtubule disruption. Cell, Vol. 89, pp.297-308, ISSN 0092-8674

Duesberg, P.; Li, R.; Fabarius, A. \& Hehlmann, R. (2006). Aneuploidy and cancer: from correlation to causation. Contributions to Microbiology, Vol.13, pp. 16-44, ISSN 14209519

Fenech, M. (2007). Cytokinesis-block micronucleus cytome assay. Nature Protocols, Vol.2, pp. 1084-1104, ISSN 1754-2189

Fujiwara, T.; Bandi, M.; Nitta, M.; Ivanova, E.V.; Bronson, R.T. \& Pellman, D. (2005). Cytokinesis failure generating tetraploids promotes tumorigenesis in p53-null cells. Nature, Vol. 437, 1043-1047, ISSN 0028-0836

Gamblin, T.C.; Chen, F.; Zambrano, A.; Abraha, A.; Lagalwar, S.; Guillozet, A.L.; Lu, M.; Fu, Y.; Garcia-Sierra, F.; LaPointe, N.; Miller, R.; Berry, R.W.; Binder, L.I. \& Cryns, V.L. (2003) Caspase cleavage of tau: linking amyloid and neurofibrillary tangles in Alzheimer's disease. Proceedings of the National Academy of Sciences of the United States of America, Vol. 100, No. 17, pp. 10032-10037, ISSN 0027-8424

Ganem, N.J.; Storchova, Z. \& Pellman, D. (2007). Tetraploidy, aneuploidy and cancer. Current Opinion in Genetics \& Development, Vol. 17, pp. 157-162, Review, ISSN 0959437X

Ganem, N.J.; Godinho, S.A. \& Pellman, D. (2009). A mechanism linking extra centrosomes to chromosomal instability. Nature, Vol. 460, pp.278-282, ISSN 0028-0836 
Geigl, J.B.; Obenauf, A.C.; Schwarzbraun, T. \& Speicher, M.R. (2008). Defining 'chromosomal instability'. Trends in Genetics, Vol. 24, pp. 64-69, ISSN 0168-9525

Ghadimi, B.M.; Sackett, D.L.; Difilippantonio, M.J.; Schröck, E.; Neumann, T.; Jauho, A.; Auer, G. \& Ried, T. (2000). Centrosome amplification and instability occurs exclusively in aneuploid, but not in diploid colorectal cancer cell lines, and correlates with numerical chromosomal aberrations. Genes Chromosomes and Cancer, Vol. 27, pp.183-190, ISSN 1045-2257

Greenman, C.; Stephens, P.; Smith, R.; Dalgliesh, G.L.; Hunter, C.; Bignell, G.; Davies, H.; Teague, J.; Butler, A.; Stevens, C.; Edkins, S.; O'Meara, S.; Vastrik, I.; Schmidt, E.E.; Avis, T.; Barthorpe, S.; Bhamra, G.; Buck, G.; Choudhury, B.; Clements, J.; Cole, J.; Dicks, E.; Forbes, S.; Gray, K.; Halliday, K.; Harrison, R.; Hills, K.; Hinton, J.; Jenkinson, A.; Jones, D.; Menzies, A.; Mironenko, T.; Perry, J.; Raine, K.; Richardson, D.; Shepherd, R.; Small, A.; Tofts, C.; Varian, J.; Webb,T.; West, S.; Widaa, S.; Yates, A.; Cahill, D.P.; Louis, D.N.; Goldstraw, P.; Nicholson, A.G.; Brasseur, F.; Looijenga, L.; Weber, B.L.; Chiew, Y.E.; De Fazio, A.; Greaves, M.F.; Green, A.R.; Campbell, P.; Birney, E.; Easton, D.F.; Chenevix-Trench, G.; Tan, M.H.; Khoo, S.K.; Teh, B.T.; Yuen, S.T.; Leung, S.Y.; Wooster, R.; Futreal, P.A. \& Stratton, M.R. (2007). Patterns of somatic mutation in human cancer genomes. Nature, Vol. 446, pp.153-158, ISSN 0028-0836

Hartmann, C.; Johnk, L.; Kitange, G.; Wu, Y.; Ashworth, L.K.; Jenkins, R.B. \& Louis, D.N. (2002). Transcript Map of the 3.7-Mb D19S112-D19S246. Cancer Research, Vol.62, pp. 4100-4108, ISSN 0008-5472

Hecht, B.K.; Turc-Carel, C.; Chatel, M.; Grellier, P.; Gioanni, J.; Attias, R.; Gaudray, P. \& Hecht, F. (1995). Cytogenetics of malignant gliomas: I. The autosomes with reference to rearrangements. Cancer Genetics and Cytogenetics, Vol. 84, pp. 1-8, ISSN 0165- 4608

Hurov, J.B.; Stappenbeck, T.S.; Zmasek, C.M.; White, L.S.; Ranganath, S.H.; Russell, J.H.; Chan, A.C.; Murphy, K.M. \& Piwnica-Worms, H. (2001). Immune system dysfunction and autoimmune disease in mice lacking Emk (Par-1) protein kinase. Molecular Cell Biology, Vol. 21, pp.3206-3219, ISSN 1098-5549

Hurov, J. \& Piwnica-Worms, H. (2007). The Par-1/MARK family of protein kinases: from polarity to metabolism. Cell cycle, Vol.6, pp. 1966-1969, ISSN 1538-4101

Jenkins, R.B.; Kimmel, D.W.; Moertel, C.A.; Schultz, C.G.; Scheithauer, B.W.; Kelly, P.J. \& Dewald, G.W. (1989). A cytogenetic study of 53 human gliomas. Cancer Genetics and Cytogenetics, Vol. 39, pp. 253-279, ISSN 0165- 4608

Kato, T.; Satoh, S.; Okabe, H.; Kitahara, O.; Ono, K.; Kihara, C.; Tanaka, T.; Tsunoda, T.; Yamaoka, Y.; Nakamura, Y. \& Furukawa, Y. (2001). Isolation of a novel human gene, MARKL1, homologous to MARK3 and its involvement in hepatocellular carcinogenesis. Neoplasia, Vol. 3, No.1, pp. 4-9, ISSN 1522-8002

Katsetos, C.D.; Reddy, G.; Dráberová, E.; Smejkalová, B.; Del Valle, L.; Ashraf, Q.; Tadevosyan, A.; Yelin, K.; Maraziotis, T.; Mishra, O.P.; Mörk, S.; Legido, A.; Nissanov, J.; Baas, P.W.; de Chadarévian, J.P. \& Dráber, P. (2006). Altered cellular distribution and subcellular sorting of gamma-tubulin in diffuse astrocytic gliomas and human glioblastoma cell lines. Journal of Neuropathology and Experimental Neurology, Vol. 65, pp. 465-477, ISSN 0022-3069 
Kitange, G.; Misra, A.; Law, M.; Passe, S.; Kollmeyer, T.M.; Maurer, M.; Ballman, K.; Feuerstein, B.G. \& Jenkins, R.B. (2005). Chromosomal imbalances detected by array comparative genomic hybridization in human oligodendrogliomas and mixed oligoastrocytomas. Genes Chromosomes and Cancer, Vol. 42, pp. 68-77, ISSN 10452257

Kleihues, P. \& Cavenee, W.K. (2000). Pathology and Genetics of Tumours of the Nervous System, IARC Press, ISBN 928322409 4, Lyon, France

Kleihues, P.\& Ohgaki, H. (2000). Phenotype vs genotype in the evolution of astrocytic brain tumors. Toxicologic Pathology, Vol. 28, No.1, pp. 164-170, ISSN 0192-6233

Koschny, R.; Koschny, T.; Froster, U.G.; Krupp, W. \& Zuber, M.A. (2002). Comparative genomic hybridization in glioma: a meta-analysis of 509 cases. Cancer Genetics and Cytogenetics, Vol. 135, pp. 147-159, ISSN 0165- 4608

Kramer, A.; Neben, K. \& Ho, AD. (2002). Centrosome replication, genomic instability and cancer. Leukemia, Vol. 16, pp. 767-775 , ISSN 0887-6924

Lengauer, C.; Kinzler, K.W. \& Vogelstein B. (1998). Genetic instabilities in human cancers. Nature, Vol. 396, pp. 643-649, ISSN 0028-0836

Lindstrom, E.; Salford, L.G. Heim S, Mandahl N, Stromblad S, Brun A, Mitelman F. (1991): Trisomy 7 and sex chromosome loss need not be representative of tumor parenchyma cells in malignant glioma. Genes, Chromosomes and Cancer, Vol. 3, pp. 474-479, ISSN 1045-2257

Lingle, W.L.; Barrett, S.L.; Negron, V.C.; D'Assoro, A.B.; Boeneman, K.; Liu, W.; Whitehead, C.M.; Reynolds, C. \& Salisbury, J.L. (2002). Centrosome amplification drives chromosomal instability in breast tumor development. Proceedings of the National Academy of Science of the United States of America, Vol. 99, pp.1978-1983, ISSN 00278424

López-Saavedra, A. \& Herrera, L.A. (2010). The role of alternative mRNA splicing in chromosome instability. Mutation research, Vol. 705, pp.246-51, ISSN 0027-5107

Louis, D.N.; Ohgaki, H.; Wiestler, O.D.; Cavenee, W.K.; Burger, P.C.; Jouvet, A.; Scheithauer, B.W. \& Kleihues, P. (2007). The 2007 WHO Classification of Tumours of the Central Nervous System. Acta Neuropathologica, Vol. 114, No.2, pp. 97-109, ISSN 0001-6322

Magnani, I.; Guerneri, S.; Pollo, B.; Cirenei, N.; Colombo, B.M.; Broggi, G.; Galli, C.; Bugiani, O.; DiDonato, S.; Finocchiaro, G. \& Fuhrman Conti, A.M. (1994). Increasing complexity of the karyotype in 50 human gliomas. Cancer Genetics and Cytogenetics, Vol. 75, pp. 77-89, ISSN 0165-4608

Magnani, I.; Chiariello, E.; Furhrman Conti, A.M. \& Finocchiaro, G. (1999). A recurrent 19q11-12 breakpoint suggested by cytogenetic and fluorescence in situ hybridization analysis of three glioblastoma cell lines. Cancer Genetics and Cytogenetics, Vol. 110, pp.82-86, ISSN 0165-4608

Magnani, I.; Novielli, C.; Bellini, M.; Roversi, G.; Bello, L. \& Larizza, L. (2009). Multiple localization of endogenous MARK4L protein in human glioma. Cellular Oncology, Vol.31, pp. 357-370, ISSN 1570-5870

Mandelkow, E.M.; Thies, E.; Trinczek, B.; Biernat, J. \& Mandelkow, E. (2004). MARK/PAR1 kinase is a regulator of microtubule-dependent transport in axons. The Journal of Cell Biology, Vol. 167, No.1, pp. 99-110, ISSN 0021-9525 
Margolis, R.L.; Lohez, O.D. \& Andreassen, P.R. (2003). G1 tetraploidy checkpoint and the suppression of tumorigenesis. Journal of Cellular Biochemistry, Vol. 88, pp. 673-683, Review, ISSN 1097-4644

Martinez-Garay, I.; Rustom, A.; Gerdes, H.H. \& Kutsche, K. (2006). The novel centrosomal associated protein CEP55 is present in the spindle midzone and the midbody. Genomics, Vol. 87, pp. 243-253, ISSN 0888-7543

Marx, A.; Nugoor, C.; Panneerselvam, S. \& Mandelkow, E. (2010). Structure and function of polarity-inducing kinase family MARK/Par-1 within the branch of AMPK/Snf1related kinases. The FASEB Journal, Vol. 24, pp. 1637-1648, ISSN 0892-6638

Matenia, D. \& Mandelkow, E.M. (2009). The tau of MARK: a polarized view of the cytoskeleton. Trends in biochemical sciences, Vol. 34, No.7, pp. 332-342, ISSN 09680004

Meraldi, P.; Honda, R. \& Nigg, E.A. (2002). Aurora-A overexpression reveals tetraploidization as a major route to centrosome amplification in p53-/- cells. The EMBO Journal, Vol. 21, pp. 483-492, ISSN 0261-4189

Moravcevic, K.; Mendrola, J.M.; Schmitz, K.R.; Wang, Y.H.; Slochower, D.; Janmey, P.A. \& Lemmon, M.A. (2010). Kinase associated-1 domains drive MARK/PAR1 kinases to membrane targets by binding acidic phospholypids. Cell, Vol. 143, pp.966-977, ISSN 0092-8674

Moroni, R.F.; De Biasi, S.; Colapietro, P.; Larizza, L. \& Beghini, A. (2006). Distinct expression pattern of microtubule-associated protein/microtubule affinity-regulating kinase 4 in differentiated neurons. Neuroscience, Vol. 143, pp. 83-94, ISSN 0306-4522

Moudjou, M. \& Bornens, M. (1994). Method of centrosome isolation from cultured animal cells. In: Cell biology: a laboratory handbook, Celis J.E., pp.595-604, Academic Press, (Ed.), ISBN 0-12-164715-3, San Diego, CA

Müller, J.; Ory, S.; Copeland, T.; Piwnica-Worms, H. \& Morrison, D.K. (2001). C-TAK1 regulates Ras signalling by phophorylating the MAPK scaffolds, KSR1. Molecular Cell, Vol. 8, pp. 983-993, ISSN 1097-2765

Mullins, J.M. \& Biesele, J.J. (1977). Terminal phase of cytokinesis in D-98S cells. The Journal of Cell Biology, Vol. 73, pp. 672-684, ISSN 0021-9525

Mullins, J.M. \& McIntosh, J.R. (1982). Isolation and initial characterization of the mammalian midbody. The Journal of Cell Biology, Vol. 94, pp.654-661, ISSN 0021-9525

Muramatsu, M.; Smetana, K. \& Busch, H. (1963). Quantitative aspects of isolation of nucleoli of the Walker carcinosarcoma and liver of the rat. Cancer Research, Vol. 23, pp. 510518, ISSN 0008-5472

Nigro, J.M.; Misra, A.; Zhang, L.; Smirnov, I.; Colman, H.; Griffin, C.; Ozburn, N.; Chen, M.; Pan, E.; Koul, D.; Yung, W.K.; Feuerstein, B.G. \& Aldape, K.D. (2005). Integrated array-comparative genomic hybridization and expression array profiles identify clinically relevant molecular subtypes of glioblastoma. Cancer Research, Vol. 65, 1678-1686, ISSN 0008-5472

Noble, M. \& Dietrich, J. (2004). The complex identity of brain tumors: emerging concerns regarding origin, diversity and plasticity. TRENDS in Neurosciences, Vol. 27, No.3, 148-154, ISSN 0166-2236

Ohgaki, H.; Schauble, B.; zur Hausen, A.; von Ammon, K. \& Kleihues, P. (1995). Genetic alterations associated with the evolution and progression of astrocytic brain tumours. Virchows Archive, Vol. 427, pp. 113-118, ISSN 0945-6317 
Park, H.S.; Maeda, T.; Mohapatra, G.; Waldman, F.M.; Davis, R.L. \& Feuerstein, B.G. (1995). Heterogeneity, poliploidy, aneusomy and 9p deletion in human glioblastoma multiforme. Cancer Genetics and Cytogenetics, Vol. 83, pp. 127-135, ISSN 0165-4608

Parsons, D.W.; Jones, S.; Zhang, X.; Lin, J.C.; Leary; R.J.; Angenendt, P.; Mankoo, P.; Carter, H.; Siu, I.M.; Gallia, G.L.; Olivi, A.; McLendon, R.; Rasheed, B.A.; Keir, S.; Nikolskaya, T.; Nikolsky, Y.; Busam, D.A.; Tekleab, H.; Diaz, L.A. Jr.; Hartigan, J.; Smith, D.R.; Strausberg, R.L.; Marie, S.K.; Shinjo, S.M.; Yan, H.; Riggins, G.J.; Bigner, D.D.; Karchin, R.; Papadopoulos, N.; Parmigiani, G.; Vogelstein, B.; Velculescu, V.E. \& Kinzler, K.W. (2008). An integrated genomic analysis of human glioblastoma multiforme. Science, Vol. 321, pp.1807-1812, ISSN 0036-8075

Pihan, G.A.; Purohit, A.; Wallace, J.; Knecht, H.; Woda, B.; Quesenberry, P. \& Doxsey, S.J. (1998). Centrosome defects and genetic instability in malignant tumors. Cancer Research, Vol. 58, pp. 3974-3985, ISSN 0008-5472

Pinkel, D.; Straume, T. \& Gray, J.W. (1986). Cytogenetic analysis using quantitative, highsensitivity, fluorescence hybridization. Proceedings of the National Academy of Science of the United States of America, Vol. 83, pp. 2934-2938, ISSN 0027-8424

Ritland, S.R.; Ganju, V. \& Jenkins, R.B. (1995). Region-specific loss of heterozygosity on chromosome 19 is related to the morphologic type of human glioma. Genes, Chromosomes and Cancer, Vol. 12, pp. 277-282, ISSN 1045-2257

Roversi, G.; Pfundt, R.; Moroni, R.F.; Magnani, I.; van Reijmersdal, S.; Pollo, B.; Straatman, H.; Larizza, L. \& Schoenmakers, E.F. (2006). Identification of novel genomic markers related to progression to glioblastoma through genomic profiling of 25 primary glioma cell lines. Oncogene, Vol. 9, pp. 1571-1583, ISSN 0950-9232

Saunders, W. (2005). Centrosomal amplification and spindle multipolarity in cancer cells. Seminars in Cancer Biology, Vol. 15, pp. 25-32, Review, ISSN 1044-579X

Schaar, B.T.; Kinoshita, K. \& McConnell, S.K. (2004). Doublecortin microtubule affinity is regulated by a balance of kinase and phosphatase activity at the leading edge of migrating neurons. Neuron, Vol. 41, pp. 203-213, ISSN 0896-6273

Schmidt, M.C.; Antweiler, S.; Urban, N.; Mueller, W.; Kuklik, A.; Meyer-Puttlitz, B; Wiestler, O.D.; Louis, D.N.; Fimmers, R. \& von Deimling, A. (2002). Impact of genotype and morphology on the prognosis of glioblastoma. Journal of Neuropathology $\mathcal{E}$ Experimental Neurology, Vol.61, pp. 321-328, ISSN 0014-4886

Schneider, A.; Laage, R.; von Ahsen, O.; Fischer, A.; Rossner, M.; Scheek, S.; Grünewald, S.; Kuner, R.; Weber, D.; Krüger, C.; Klaussner, B.; Götz, B.; Hiemisch, H.; Newrzella, D.; Martin-Villalba, A.; Bach, A. \& Schwaninger, M. (2004). Identification of regulated genes during permanent focal cerebral ischemia: characterization of the protein kinase 9b5/MARKL1/MARK4. Journal of Neurochemistry, Vol. 88, pp. 11141126, ISSN 1474-1644

Schwarzacher, H.G. \& Wachtler, F. (1983). Nucleolus organizer regions and nucleoli. Human genetics, Vol. 63, pp. 89-99, ISSN 0340-6717

Segu, L.; Pascaud, A.; Costet, P.; Darmon, M. \& Buhot, M.C. (2008). Impairment of spatial learning and memory in ELKL Motif Kinase 1 (EMK1/MARK2) knockout mice. Neurobiology of aging, Vol. 29, pp. 231-24, ISSN 0197-4580

Shapiro, J.R. (2002). Genetic alterations associated with adult diffuse astrocytic tumors. American Journal of Medical Genetics, Vol.115, pp. 194-201, ISSN 1552-4833 
Sluder, G. \& Nordberg, J.J. (2004). The good, the bad and the ugly: the practical consequences of centrosome amplification. Current Opinion in Cell Biology, Vol. 16, pp.49-54, Review, ISSN 09550674

Smith, J.S.; Alderete, B.; Minn, Y.; Borell, T.J.; Perry, A.; Mohapatra, G.; Hosek, S.M.; Kimmel, D.; O'Fallon, J.; Yates, A.; Feuerstein, B.G.; Burger, P.C.; Scheithauer, B.W. \& Jenkins, R.B. (1999). Localization of common deletion regions on $1 p$ and $19 q$ in human gliomas and their association with histological subtype. Oncogene, Vol. 18, pp. 4144-415, ISSN 0950-9232

The Cancer Genome Atlas (TGCA) Research Network. (2008). Comprehensive genomic characterization defines human glioblastoma genes and core pathways. Nature, Vol. 455, No.7216, pp. 1061-1068, ISSN 0028-0836

Thiel, G.; Losanowa, T.; Kintzel, D.; Nisch, G.; Martin, H.; Vorpahl, K. \& Witkowski, P. (1992). Karyotypes in 90 human gliomas. Cancer Genetics and Cytogenetics, Vol. 58, pp. 109-120, ISSN 0165- 4608

Timm, T.; Marx, A.; Panneerselvam, S.; Mandelkow, E. \& Mandelkow, E.M. (2008). Structure and regulation of MARK, a kinase involved in abnormal phosphorylation of Tau protein. BMC Neuroscience, Vol. 9, Suppl 2, S9, ISSN 1471-2202

Tochio, N.; Koshiba, S.; Kobayashi, N.; Inoue, M.; Yabuki, T.; Aoki, M.; Seki, E.; Matsuda, T.; Tomo, Y.; Motoda, Y.; Kobayashi, A.; Tanaka, A.; Hayashizaki, Y.; Terada, T.; Shirouzu, M.; Kigawa, T. \& Yokoyama, S. (2006). Solution structure of the kinaseassociated domain 1 of mouse microtubule-associated protein/microtubule affinity-regulating kinase 3. Protein science, Vol. 15, 2534-2543, ISSN 1469-896X

Trinczek, B.; Brajenovic, M.; Ebneth, A. \& Drewes, G. (2004). MARK4 is a novel Microtubuleassociated Proteins/Microtubule Affinity-regulating Kinase that binds to the cellular microtubule network and to centrosomes. The Journal of Biological Chemistry, Vol. 279, No. 7, pp. 5915-5923, ISSN 0021-9258

van den Bent, M.J.(2004). Advances in the biology and treatment of oligodendrogliomas. Current Opinion in Neurology, Vol. 17, pp.675-680, Review, ISSN 13507540

Visintin, R. \& Amon, A. (2000). The nucleolus: the magician's hat for cell cycle tricks. Current Opinion in Cell Biology, Vol. 12, No. 3, pp. 372-37, ISSN 09550674

von Deimling, A.; Louis, D.N.; von Ammon, K.; Petersen, I.; Wiestler, O.D. \& Seizinger, B.R. (1992). Evidence for a tumor suppressor gene on chromosome 19q associated with human astrocytomas, oligodendrogliomas, and mixed gliomas. Cancer Research, Vol. 52, pp.4277-4279, ISSN 0008-5472

von Deimling, A.; von Ammon, K.; Schoenfeld, D.; Wiestler, O.D.; Seizinger, B.R.\& Louis, D.N. (1993). Subsets of glioblastoma multiforme defined by molecular genetic analyis. Brain Pathology, Vol. 3, pp.19-26, ISSN 1750-3639

von Deimling, A.; Nagel, J.; Bender, B; Lenartz, D.; Schramm, J.; Louis, D.N. \& Wiestler, O.D.(1994). Deletion mapping of chromosome 19 in human gliomas. International Journal of Cancer, Vol. 57, pp.676-680, ISSN 1097-0215

Weaver, B.A.; Silk, A.D.; Montagna, C.; Verdier-Pinard, P.\& Cleveland, D.W. (2007). Aneuploidy acts both oncogenically and as a tumor suppressor. Cancer Cell , Vol.11, No.1, pp. 25-36 , ISSN 1535-6108

Wojcik, C. \& DeMartino, G.N. (2003). Intracellular localization of proteasomes. The International Journal of Biochemistry \& Cell Biology, Vol. 35, No.5, pp. 579-5, ISSN 1357-2725 89 
Zhang, H.; Ma, X.; Shi, T.; Song, Q.; Zhao, H. \& Ma, D. (2010). NSA2, a novel nucleolus protein regulates cell proliferation and cell cycle. Biochemical and Biophysical Research Communications, Vol. 391, No.1, p. 65, ISSN 0006-291X

Zhu, Y. \& Parada, L.F. (2002). The molecular and genetic basis of neurological tumours. Nature Reviews Cancer , Vol. 2, pp. 616-626, ISSN 1474-175X 


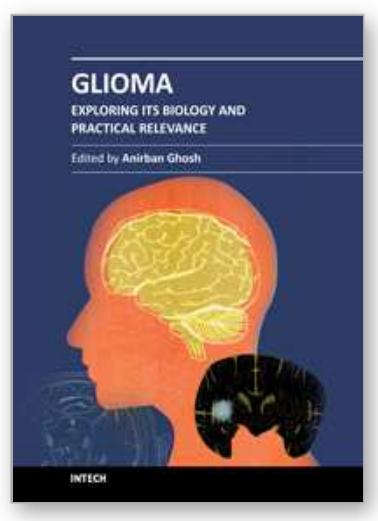

\author{
Glioma - Exploring Its Biology and Practical Relevance \\ Edited by Dr. Anirban Ghosh
}

ISBN 978-953-307-379-8

Hard cover, 486 pages

Publisher InTech

Published online 02, November, 2011

Published in print edition November, 2011

The tittle 'Glioma - Exploring Its Biology and Practical Relevance' is indicative of its content. This volume contains 21 chapters basically intended to explore glioma biology and discussing the experimental model systems for the purpose. It is hoped that the present volume will provide supportive and relevant awareness and understanding on the fundamental advances of the subject to the professionals from any sphere interested about glioma.

\title{
How to reference
}

In order to correctly reference this scholarly work, feel free to copy and paste the following:

Ivana Magnani, Chiara Novielli and Lidia Larizza (2011). Role of the Centrosomal MARK4 Protein in Gliomagenesis, Glioma - Exploring Its Biology and Practical Relevance, Dr. Anirban Ghosh (Ed.), ISBN: 978953-307-379-8, InTech, Available from: http://www.intechopen.com/books/glioma-exploring-its-biology-andpractical-relevance/role-of-the-centrosomal-mark4-protein-in-gliomagenesis

\section{INTECH}

open science | open minds

\section{InTech Europe}

University Campus STeP Ri

Slavka Krautzeka 83/A

51000 Rijeka, Croatia

Phone: +385 (51) 770447

Fax: +385 (51) 686166

www.intechopen.com

\section{InTech China}

Unit 405, Office Block, Hotel Equatorial Shanghai

No.65, Yan An Road (West), Shanghai, 200040, China

中国上海市延安西路65号上海国际贵都大饭店办公楼 405 单元

Phone: +86-21-62489820

Fax: +86-21-62489821 
(C) 2011 The Author(s). Licensee IntechOpen. This is an open access article distributed under the terms of the Creative Commons Attribution 3.0 License, which permits unrestricted use, distribution, and reproduction in any medium, provided the original work is properly cited. 